بر آورد يارامترهاى زنتيكى، تركيب يذيرى عمومى و خصوصى تودههاى بومى گثنيز ايران

امير قلىزاده'، حميد دهقانى r.** و مصطفى خدادادى"

$$
\begin{aligned}
& \text { 1- دانشجوى دكترى، كروه اصلاح نباتات، دانشكده كثاورزى، دانشگاه تربيت مدرس، تهران }
\end{aligned}
$$

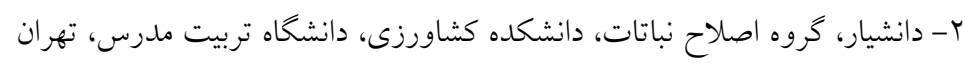

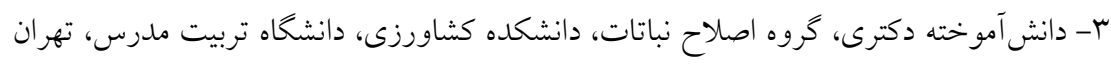

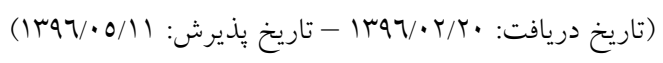

در هر برنامه اصلاحى، آكاهى از نوع عمل زنهاى كنترلكننده توارث صفات اهميت فراوانى دارد. در اين تحقيق به منظور

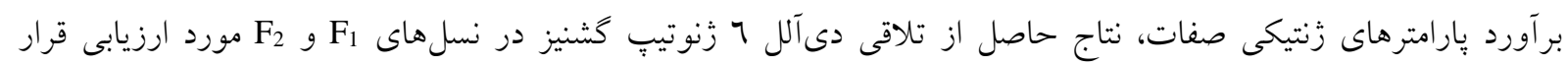

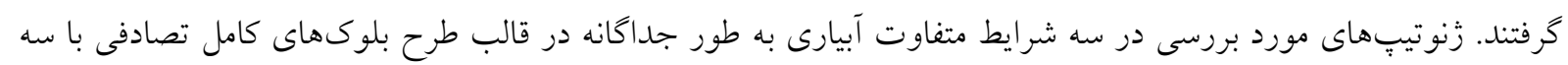

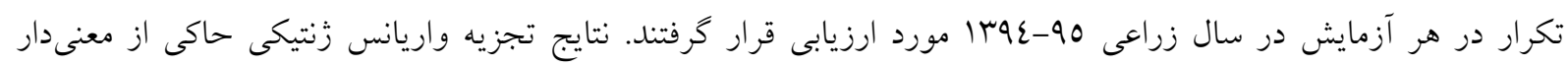

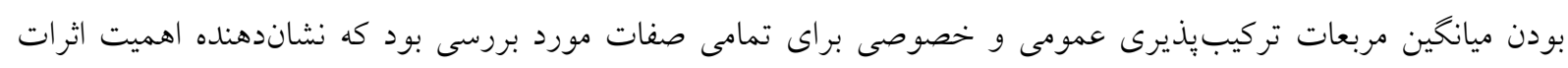

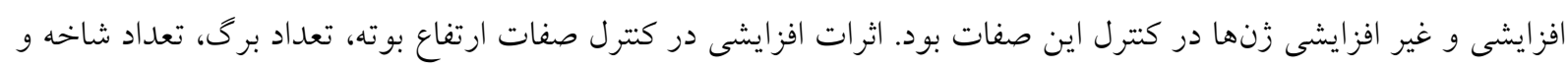

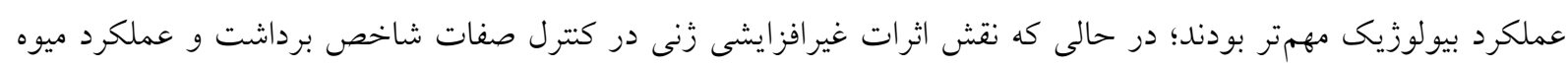

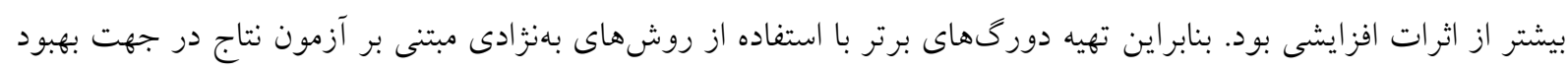

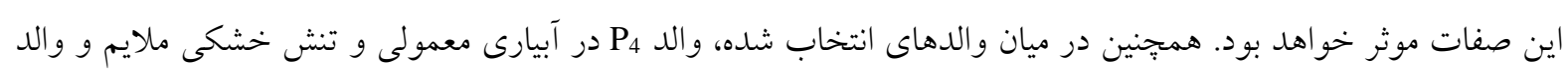

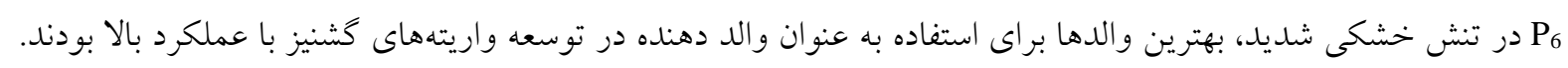

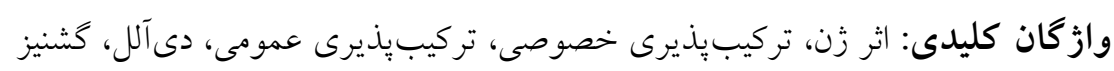


براى دستيابى به اين اهداف، ابتدا بايد تودههاى مختلف از

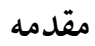

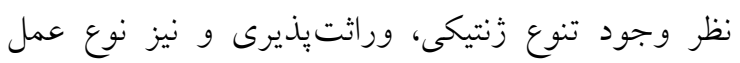

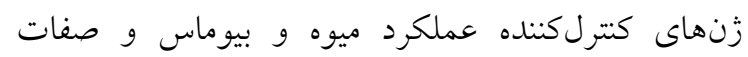

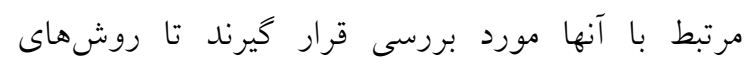

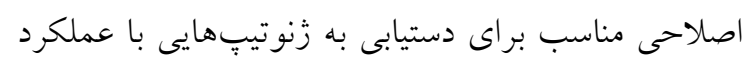

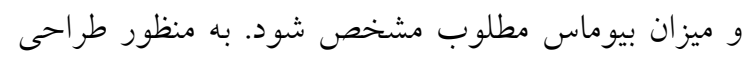

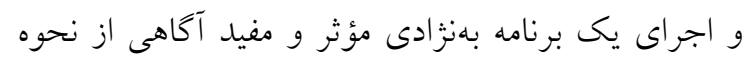

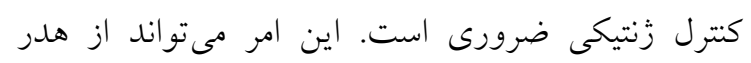
رفتن وقت و انرزى در مراحل بعدى جلو گيرى نمايد. ارقام داراى تركيب بذيرى عمومى ( General Combining

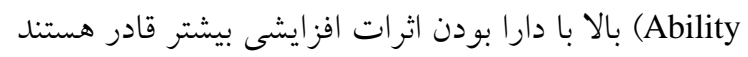

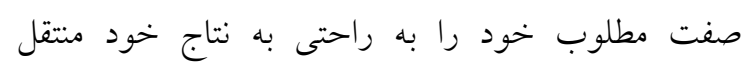
نمايند. از ارقام داراى تركيب پيذيرى خصوصى ( Specific بالا نيز مىتوان در برنامههاى (Combining Ability

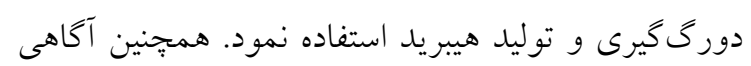

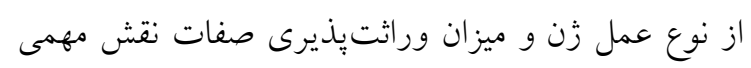

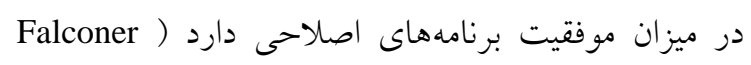

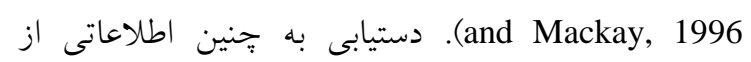
طريق طرحهاى تلاقى مانند تلاقىهاى دىآلل، تجزيه

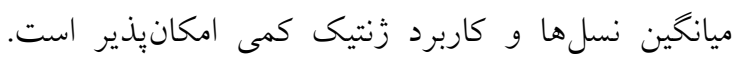

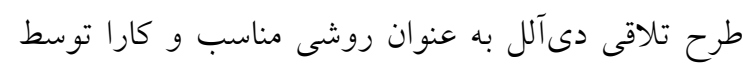

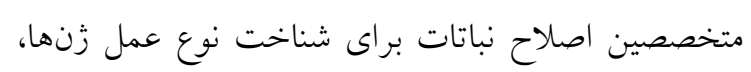

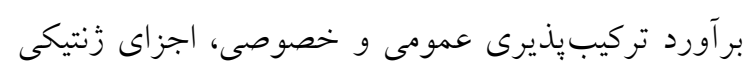

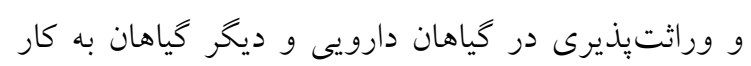

كرفته شده است ) 2012; Townsend et al., 2013; Sadeghzadeh-Ahari et al., 2015; Mohammadi and Roustaie, 2016; Khodadadi et al., 2016b; Khodadadi et al., 2017; (Valizadeh et al., 2017

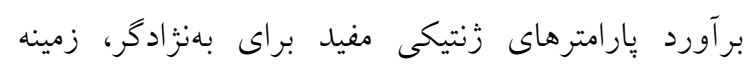

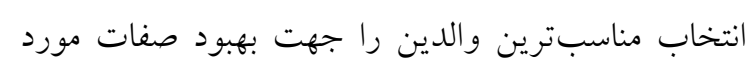

نظر فراهم مى كند (Griffing, 1956).

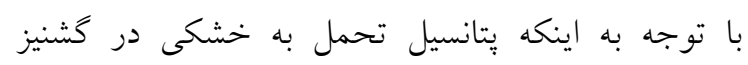

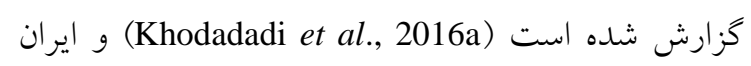

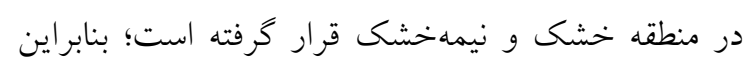
مطالعه در زمينه نحوه كنترل زنتيكى صفات عملكرد ميوه 
آزمايش دوم (تنش ملايم) در مرحله اول، از زمان

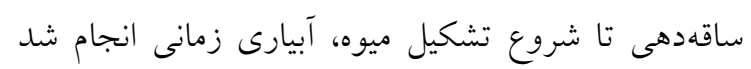

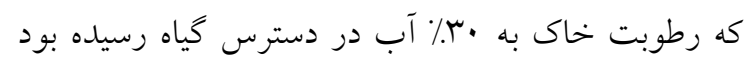

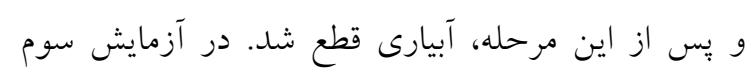

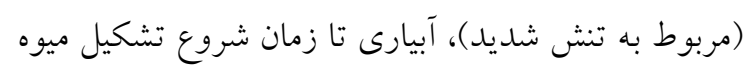
بصورت نرمال انجام و پِ از اين مرحله آبيارى قطع شد. همجنين در طول فصل رشد، كوددهى با توجه به نياز كياه

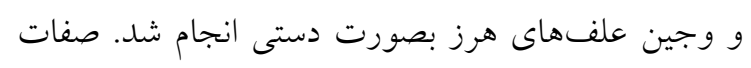
اندازهيرى شده در اين آزمايش شامل، ارتفاع گياه، تعداد

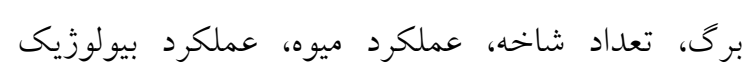

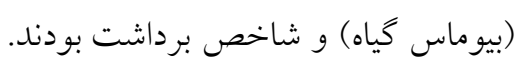

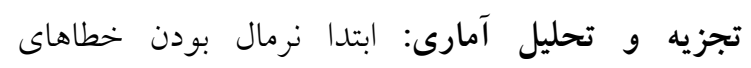

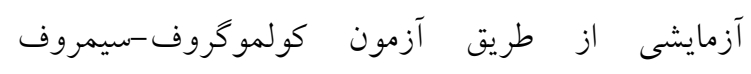
(Kolmogorov, 1933; Smirnov, 1948) همخنى واريانسهاى درون تيمارى با استفاده از نرم

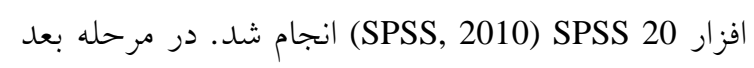
تجزيه واريانس مركب بر روى صفات انجام يذيرفت. مقايسات ميانخين صفات در محيطهاى مختلف به طور

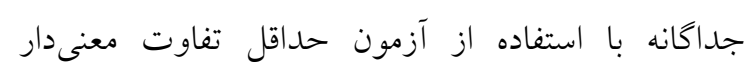

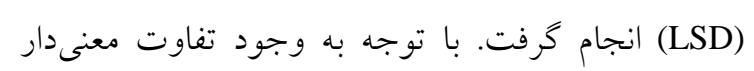

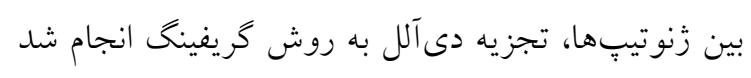

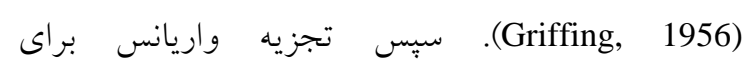
تركيبذيذيرى عمومى (GCA) و تركيب يذيرى خصوصى (GCA)

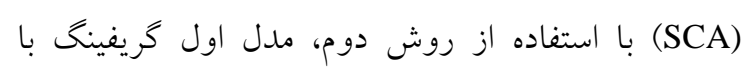

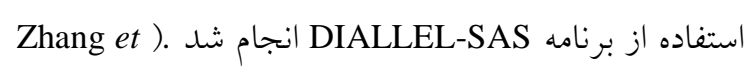
.al., 2005 برآوردهاى و واريانس تركيبِّيرى عمومى ( واريانس تركيبيذيرى خصوصى ( ${ }^{2}$ ) جهت تخمين واريانس افزايشى (

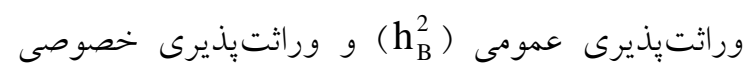
Zhang et ). با استفاده از مدل تصادفى انجام كرفت (h)

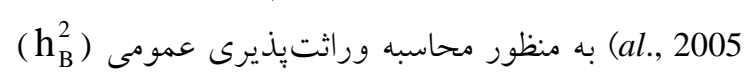

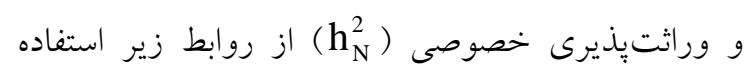

شد (Kalb and Davis, 1984).
و ميزان بيوماس توليدى و همجنين صفات مرتبط با آنها

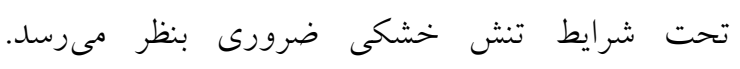

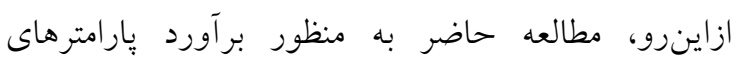

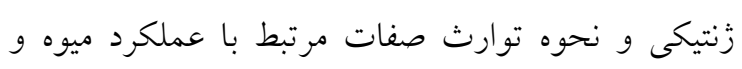

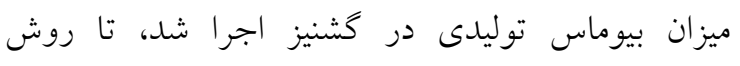

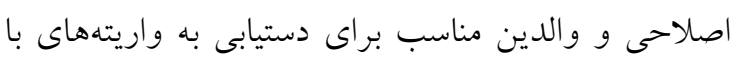
عملكرد ميوه و ميزان بيوماس بالا مشخص ول شود.

مواد و روشها در اين مطالعه از 7 توده بومى گشنيز شامل توده تجارى

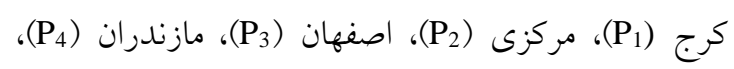

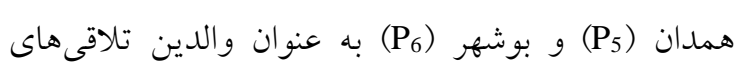
دى آلل يكطرفه استفاده شد. در انتخاب والدين ضمن ونه

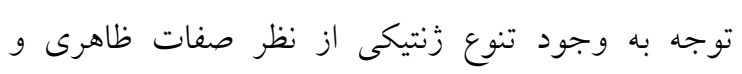

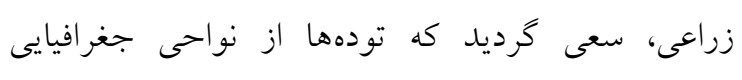

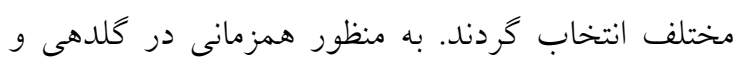

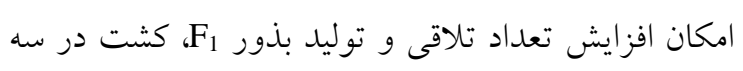
تاريخ كشت با فواصل دو هفتهاى در كلخانه و مزرعه

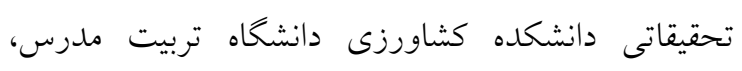

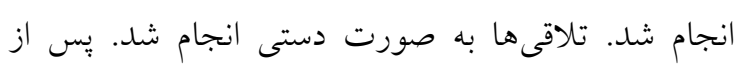
حصول بذر F1 بخشى از بذور هر تلاقى جهت توليد بذ بذور

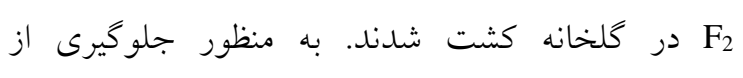
دكركردهافشانى توسط حشرات، هر بوته درانه در مرحله

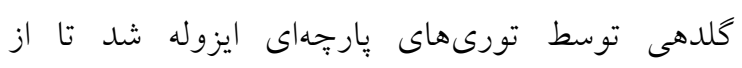

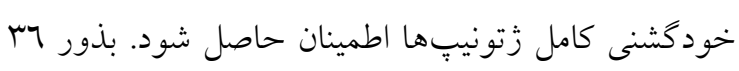

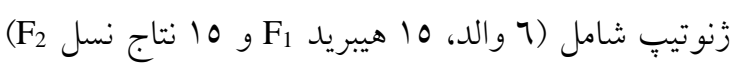

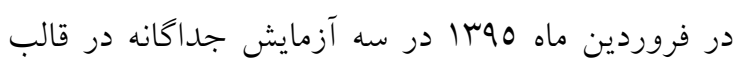
طرح بلوكهاى كامل تصادفى با سه تكرار در مزرعه

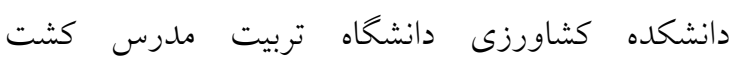

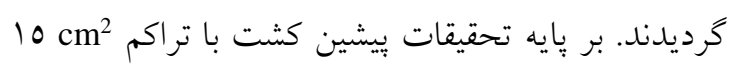

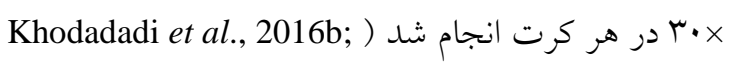
Khodadadi et al., 2017 براى زنوتيبها در آزمايشهاى مختلف به صورتى بود كه آنه

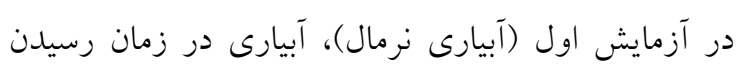

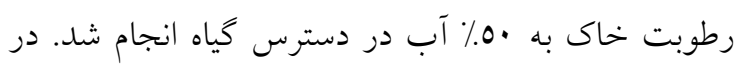


انتهايى رشد كياه است كه به طور معنىدارى تحت تأثير

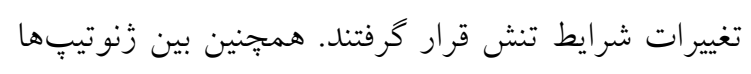

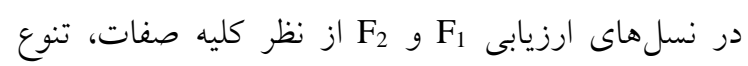

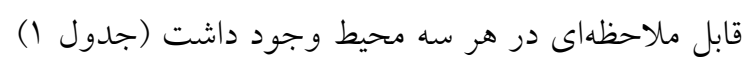

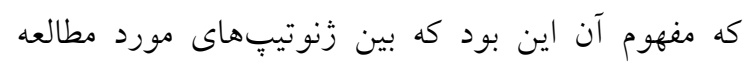

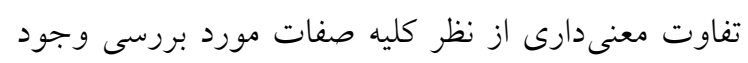

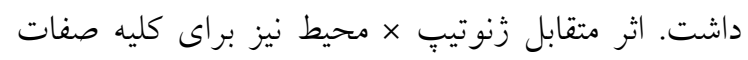

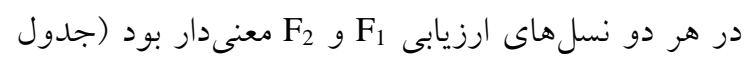

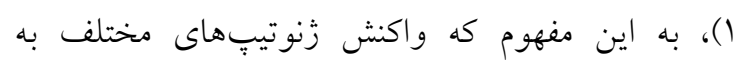
شرايط متفاوت بدون تنش و تنش خشكى يكسان نبوده

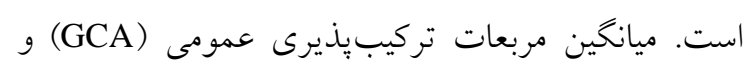

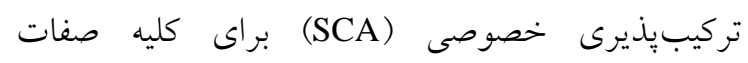

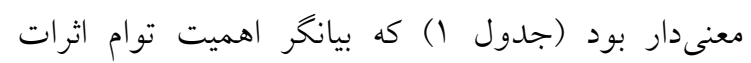

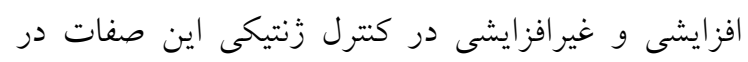

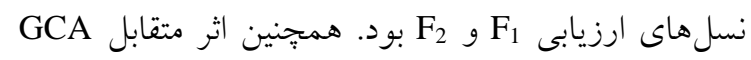

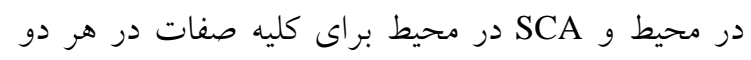

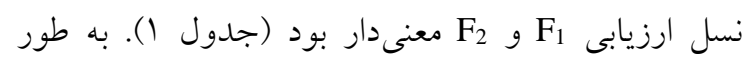

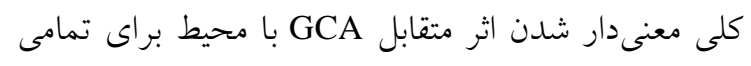
صفات، حساسيت اثر افزايشى زنهاى كنترلكننده اين

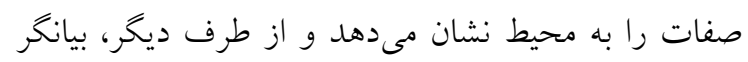

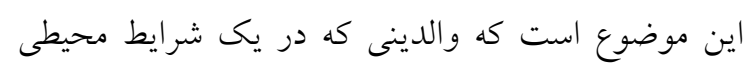
(بدون تنش يا تنش خشكى) از GCA مناسبى برخوردار

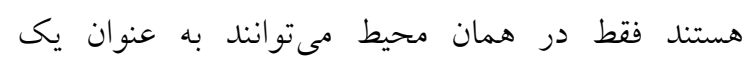

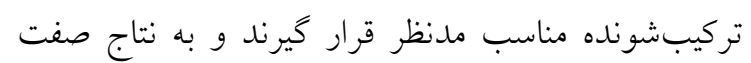

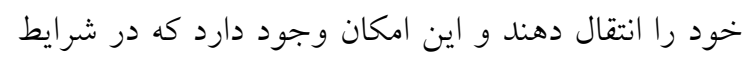

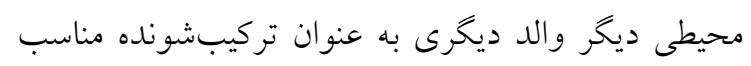

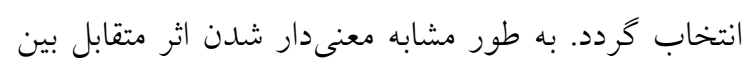

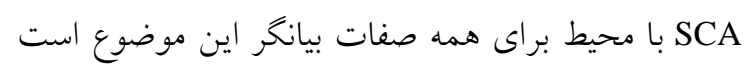
كه در هر شرايط (بدون تنش و تنش خشكى) تركيبات

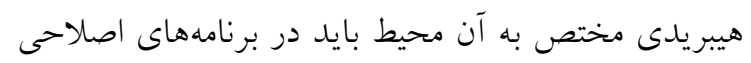

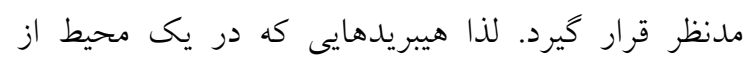

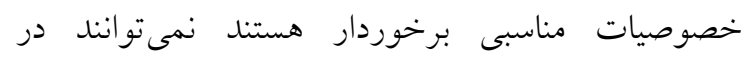
محيطهاى ديخر همان بازدهى را داشته باشند كه دليل

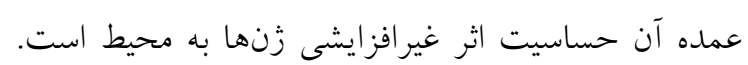

$$
\begin{gathered}
\mathrm{h}_{\mathrm{B}}^{2}=\frac{\sigma_{\mathrm{A}}^{2}+\sigma_{\mathrm{D}}^{2}}{\sigma_{\mathrm{A}}^{2}+\sigma_{\mathrm{D}}^{2}+\frac{\sigma_{\mathrm{E}}^{2}}{\mathrm{r}}} \\
\mathrm{h}_{\mathrm{N}}^{2}=\frac{\sigma_{\mathrm{A}}^{2}}{\sigma_{\mathrm{A}}^{2}+\sigma_{\mathrm{D}}^{2}+\frac{\sigma_{\mathrm{E}}^{2}}{\mathrm{r}}}
\end{gathered}
$$

براى محاسبه واريانس افزايشى و غالبيت از فرمولهاى زير استفاده شد (Griffing, 1956).

$$
\begin{aligned}
& \sigma_{\mathrm{A}}^{2}=\frac{4}{1+\mathrm{F}} \sigma_{\mathrm{GCA}}^{2} \\
& \sigma_{\mathrm{D}}^{2}=\frac{4}{(1+\mathrm{F})^{2}} \sigma_{\mathrm{SCA}}^{2}
\end{aligned}
$$

رابطه ع

كه در آن

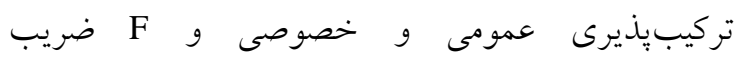
خويشآميزى است. در اين مطالعه به علت استفاده از

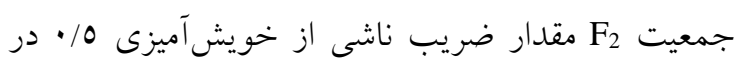
نظر كرفته شد. همجنين در اين مطالعه از شاخص عامل

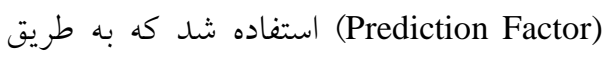

تشخيص ذيل محاسبه مىشود (Baker, 1978). $\mathrm{PF}=\frac{2 \sigma_{\mathrm{g}}^{2}}{2 \sigma_{\mathrm{g}}^{2}+\sigma_{\mathrm{s}}^{2}}$ رابطه از فاكتور تشخيص به عنوان معيارى جهت مقايسه اهميت نسبى واريانس تركيبِّيرى عمومى (

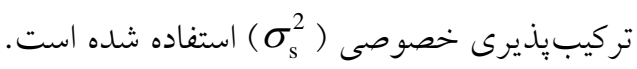

\section{نتايج و بحث} تجزيه واريانس مركب صفات: نتايج نشان داد كه اثر

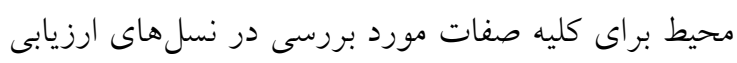
F1 و F2 $F_{2}$

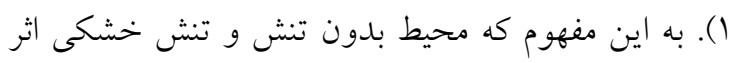

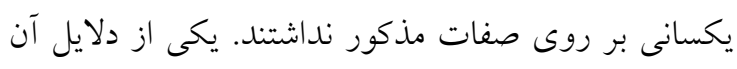

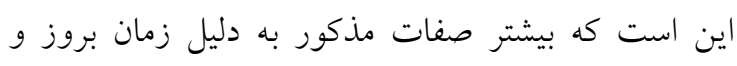
تكميل شدن آنها و عوامل ديخر، بيشتر تحت تأثير عوامل

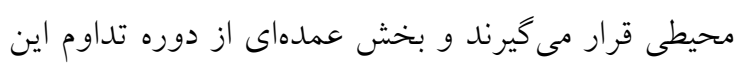

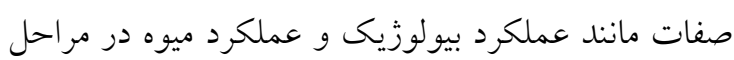


سانتىمتر) بود. در اين شرايط بيشترين مقدار تعداد برى

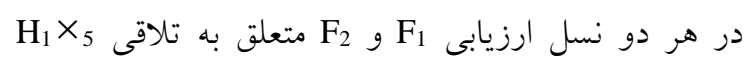

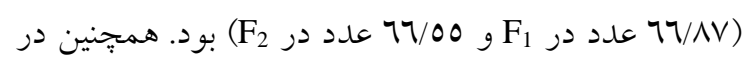

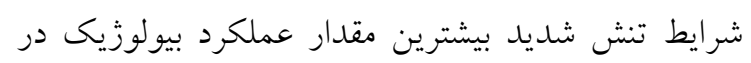

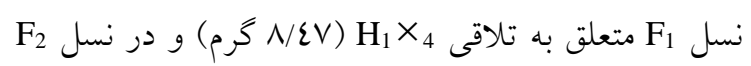
متعلق به تلاقى

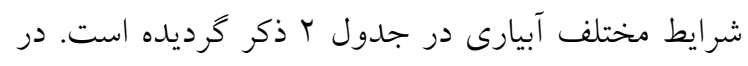

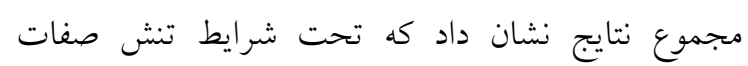

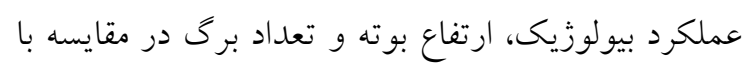

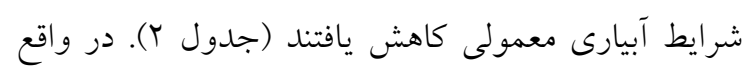

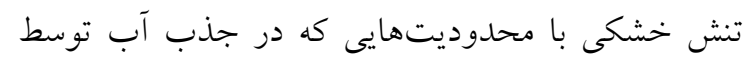

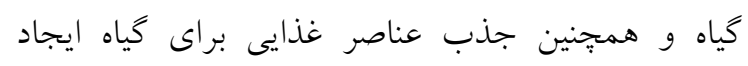
مىكند باعث كاهش بيوماس توليدى مىشود ( Ashraf

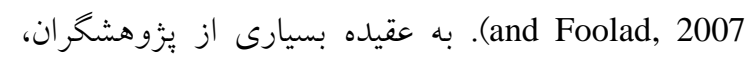

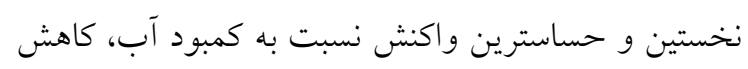

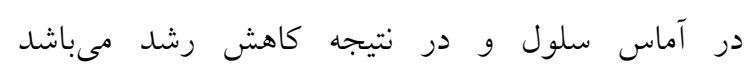

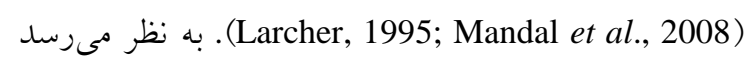
كه كاهش عملكرد و رشد گياه گشنيز تحت تنش در

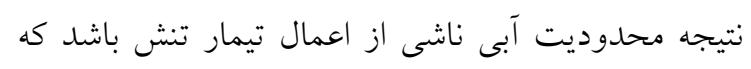

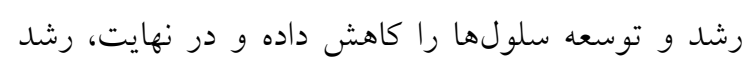

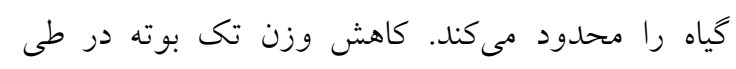
افزايش سطح تنش خشكى مىتواند مربوط به به كاهش

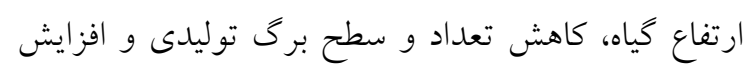

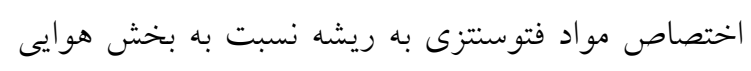

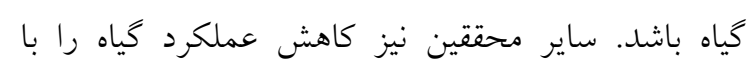
Sreevalli et al., ) افزايش شدت تنش كزارش كردهاه .(2001; Tawfik, 2008; Ahmadian et al., 2011 تأثير سطوح مختلف تنش خشكى بر تعداد شاخه كياه

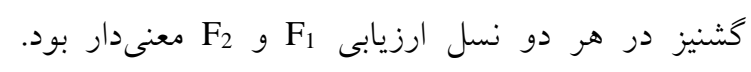

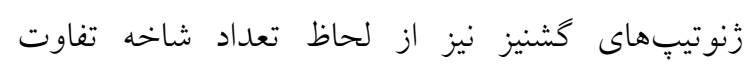

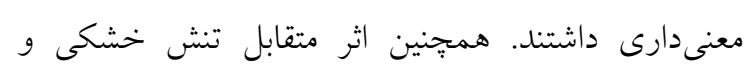
زنوتيِّ براى اين صفت معنى دار بود (جدول (1).
بنابراين معنى دار شدن اثر متقابل GCA با محيط و SCA با

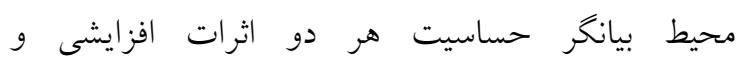

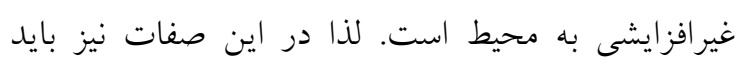

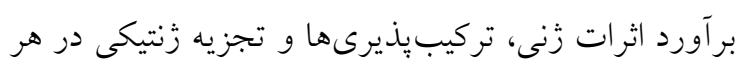
محيط به طور جداكانه صورت كيرد. مطالعات نشان داده

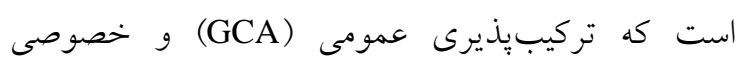
براى اكثر صفات در كثنيز، با تغييرات محيطى (SCA)

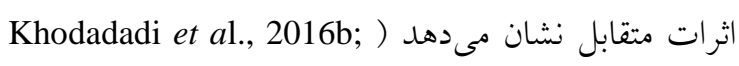
Khodadadi et al., 2017

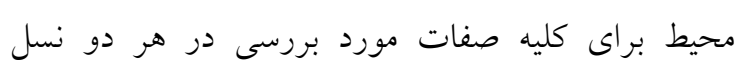

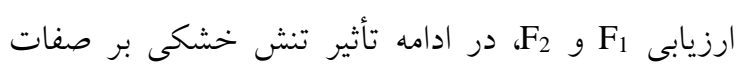
مورد بررسى مورد بحث قرار گرفت. اثر تنش خشكى بر صفات مورد بررسى: تأثير تنش بردي

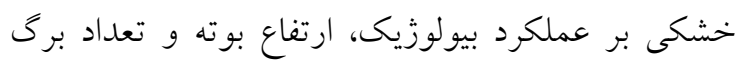

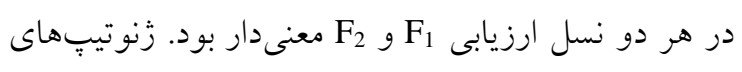

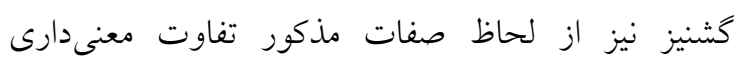

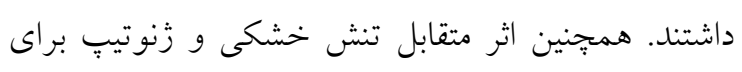

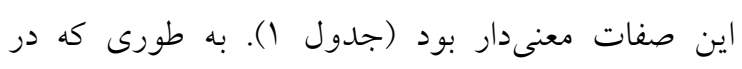

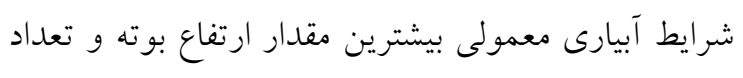

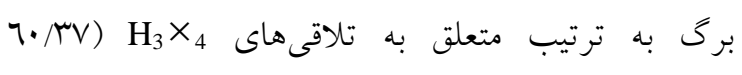

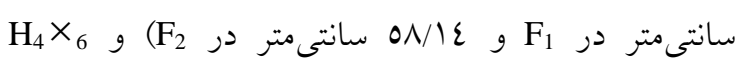

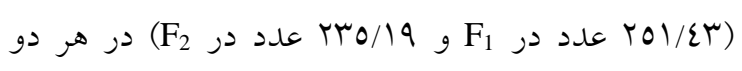

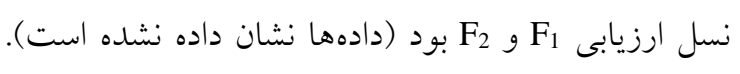
همجنين در شرايط آبيارى معمولى، بيشترين مقدار

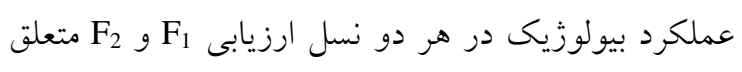
به تلاقى بود. در شرايط تنش ملايم بيشترين مقدار ارتفاع بوته درم

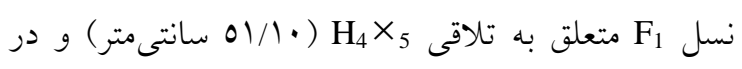

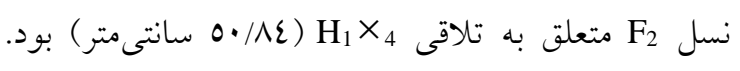

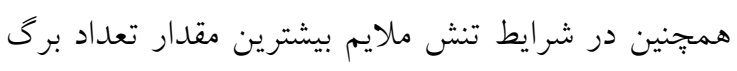

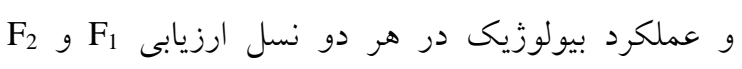

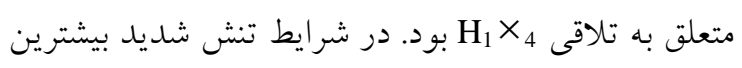

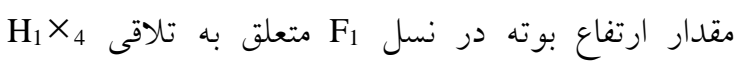

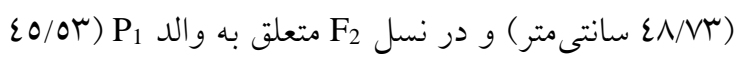




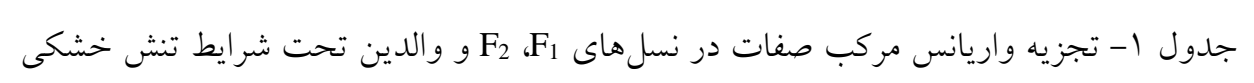

Table 1. Combined analysis of variance for traits in the $\mathrm{F}_{1}$ and $\mathrm{F}_{2}$ progenies and their parents under drought stress condition

\begin{tabular}{|c|c|c|c|c|c|c|c|c|c|c|c|c|c|}
\hline \multirow{3}{*}{ Source } & \multirow{3}{*}{ df } & \multicolumn{12}{|c|}{ Mean Squares } \\
\hline & & \multicolumn{2}{|c|}{$\mathrm{PH}$} & \multicolumn{2}{|c|}{ NL } & \multicolumn{2}{|c|}{$\mathrm{BN}$} & \multicolumn{2}{|c|}{$\mathrm{BY}$} & \multicolumn{2}{|c|}{ FY } & \multicolumn{2}{|c|}{$\mathrm{HI}$} \\
\hline & & $F_{1}$ & $\mathrm{~F}_{2}$ & $F_{1}$ & $\mathrm{~F}_{2}$ & $F_{1}$ & $\mathrm{~F}_{2}$ & $F_{1}$ & $\mathrm{~F}_{2}$ & $\mathrm{~F}_{1}$ & $\mathrm{~F}_{2}$ & $\mathrm{~F}_{1}$ & $\mathrm{~F}_{2}$ \\
\hline Environment (E) & 2 & $1019.62^{* *}$ & $1312.24^{* * *}$ & $228171.67^{* *}$ & $212208.99^{* * *}$ & $748.53^{* *}$ & $731.13^{* *}$ & $5750.33^{* *}$ & $4921.54^{* *}$ & $1162.69^{* *}$ & $686.94^{* *}$ & $0.50^{* *}$ & $0.17^{* *}$ \\
\hline Replication (E) & 6 & 8.16 & 6.42 & 32.03 & 138.97 & 0.91 & 1.10 & 8.24 & 9.01 & 13.61 & 12.55 & 0.14 & 0.17 \\
\hline Genotype (G) & 20 & $192.64^{* *}$ & $155.84^{* * *}$ & $4022.92^{* *}$ & $3635.45^{* *}$ & $24.22^{* *}$ & $17.52^{* *}$ & $243.06^{* * *}$ & $196.05^{* *}$ & $114.30^{* *}$ & $58.60^{* *}$ & $1.23^{* *}$ & $0.81^{* *}$ \\
\hline$G \times E$ & 40 & $26.11^{* *}$ & $20.45^{* *}$ & $2032.50^{* *}$ & $1670.03^{* *}$ & $4.78^{* *}$ & $2.52^{* *}$ & $91.65^{* *}$ & $73.62^{* * *}$ & $11.42^{* *}$ & $5.80^{* *}$ & $0.13^{* *}$ & $0.08^{* *}$ \\
\hline GCA & 5 & $676.80^{* *}$ & $583.70^{* *}$ & $13825.23^{* *}$ & $12624.05^{* *}$ & $76.23^{* *}$ & $61.43^{* *}$ & $781.85^{* *}$ & $650.45^{* *}$ & $225.29^{* *}$ & $138.37^{* *}$ & $2.80^{* *}$ & $2.01^{* *}$ \\
\hline SCA & 15 & $31.26^{* *}$ & $13.22^{* *}$ & $755.49^{* * *}$ & $639.25^{* *}$ & $6.88^{* *}$ & $2.89^{* *}$ & $63.47^{* * *}$ & $44.59^{* *}$ & $77.31^{* *}$ & $32.01^{* *}$ & $0.71^{* *}$ & $0.40^{* *}$ \\
\hline $\mathrm{GCA} \times \mathrm{E}$ & 10 & $51.95^{* *}$ & $43.69^{* *}$ & $5842.80^{* *}$ & $5196.40^{* *}$ & $8.86^{* *}$ & $4.79^{* *}$ & $256.978^{* *}$ & $207.24^{* *}$ & $25.57^{* *}$ & $15.35^{* *}$ & $0.18^{* *}$ & $0.10^{* * *}$ \\
\hline $\mathrm{SCA} \times \mathrm{E}$ & 30 & $17.49^{* *}$ & $12.70^{* *}$ & $762.39^{* *}$ & $494.57^{* *}$ & $3.42^{* *}$ & $1.76^{* *}$ & $36.545^{* *}$ & $29.08^{* * *}$ & $6.70^{* *}$ & $2.61^{* *}$ & $0.12^{* *}$ & $0.07^{* *}$ \\
\hline Error & 120 & 6.76 & 4.30 & 138.97 & 135.96 & 1.25 & 0.69 & 6.68 & 6.06 & 1.12 & 1.10 & 0.02 & 0.03 \\
\hline
\end{tabular}

${ }^{* *}$ is significant at $1 \%$ level of probability. Plant height $(\mathrm{PH})$, number of leaf $(\mathrm{NL})$, branch number (BN), biological yield (BY), fruit yield (FY), harvest index (HI), general combining ability (GCA), specific combining ability (SCA)

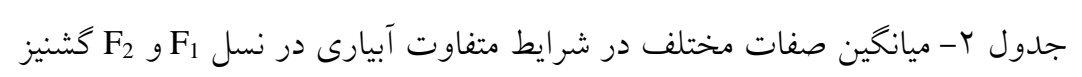

\begin{tabular}{|c|c|c|c|c|c|c|c|c|c|c|c|c|}
\hline \multirow{2}{*}{ Water treatment } & \multicolumn{6}{|c|}{$\mathrm{F}_{1}$} & \multicolumn{6}{|c|}{$\mathrm{F}_{2}$} \\
\hline & PH & NL & BN & BY & FY & HI & $\mathrm{PH}$ & NL & $\mathrm{BN}$ & BY & FY & HI \\
\hline Well Watered & 49.72 & 162.84 & 13.19 & 24.13 & 11.08 & 0.52 & 49.41 & 160.03 & 13.13 & 22.87 & 8.83 & 0.45 \\
\hline Moderate Water Stress & 43.48 & 64.33 & 9.23 & 9.45 & 5.42 & 0.63 & $42.09^{\mathrm{b}}$ & $63.64^{\mathrm{b}}$ & 9.04 & 9.43 & 4.46 & 0.51 \\
\hline Sever Water Stress & 42.20 & 53.69 & 6.32 & 6.20 & 2.66 & 0.45 & 41.03 & 55.82 & 6.37 & 6.21 & 2.36 & 0.41 \\
\hline
\end{tabular}

Table 2. The mean of different traits under different irrigation conditions in $F_{1}$ and $F_{2}$ generations of coriander

Plant height (PH), number of leaf (NL), branch number (BN), biological yield (BY), fruit yield (FY), harvest index (HI) 
كرم) و در نسل F متعلق به تلاقى بود. در شرايط تنش ملايم بيشترين مقدار عملكرد ميوه در

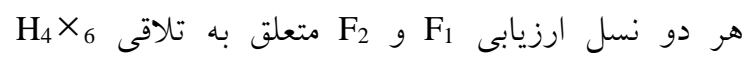

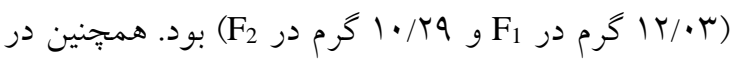
شرايط تنش شديد بيشترين مقدار عملكرد ميوه در نسل

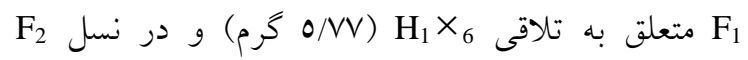
متعلق به تلاقى

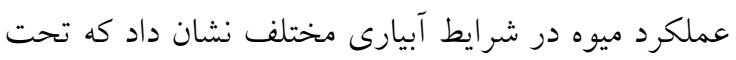
شرايط تنش خشكى عملكرد ميوه در مقايسه با شرايط

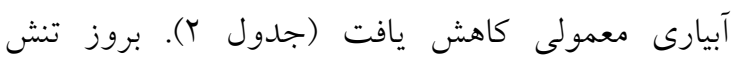
خشكى طى مراحل مختلف نموى مخصوصاً مرحله زايشى سبب كاهش طول دوره فتوسنتزى، انتقال مواد حاصل از فتوسنتز جارى به دانه، سهم انتقال مجدد مواد ذخيره شده ساقه به دانه و در نهايت كاهش عملكرد دانه مىشود. تنش خشكى علاوه بر محدود كردن منبع (كاهش

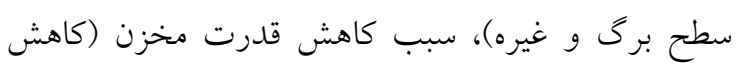
تعداد دانه در جتر و غيره) و ظرفيت ذخيرهاى مى شود

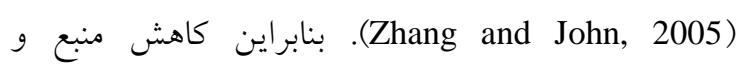
فتوسنتز جارى از طرفى و كاهش مقدار انباشت و انتقال مجدد مواد از طرفى ديخر، موجب كاهش عمكرد دانه

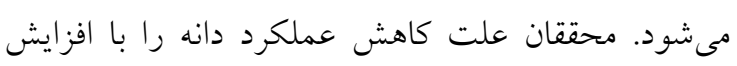

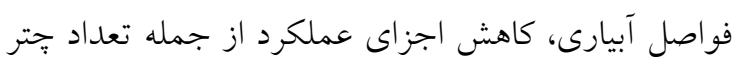

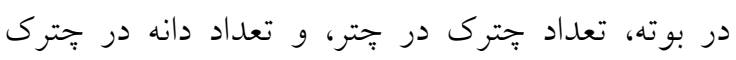
Zنوان كردهاند (-) عehtab-Salmasi et al., 2006; Noroozi

.(Shahri et al., 2015

تأثير سطوح مختلف تنش خشكى بر شاخص برداشت

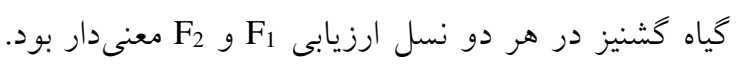

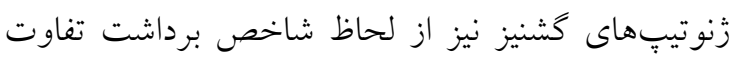
معنى دارى داشتند. همجِنين اثر متقابل تنش خشكى ورى و زنوتيبٍ براى اين صفت معنىدار بود (جدول () ). به طورى كه در شرايط آبيارى معمولى بيشترين مقدار

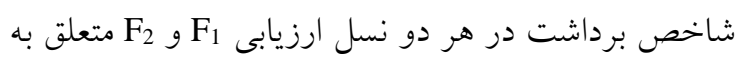

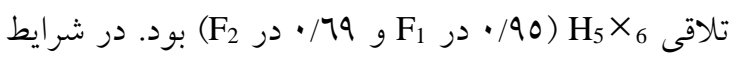

در شرايط آبيارى معمولى بيشترين مقدار تعداد شاخه در

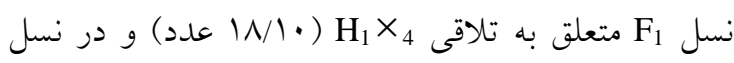

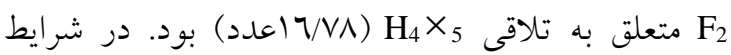
تنش ملايم بيشترين مقدار تعداد شاخه در نسل Fi متعلق به تلاقى تلاقى شديد بيشترين مقدار تعداد شاخه در هر دو نسل ارزيابى F و F F F F Fلق به تلاقى $F_{1}$ عدد در F2) بود. نتايج نشان داد كه تحت شرايط تنش خشكى صفت تعداد شاخه در مقايسه با شرايط آبيارى معمولى كاهش يافت (جدول Y). علت كاهش رشد و تعداد شاخه در تنش خشكى اينطور بيان شده است كه فعاليت انزيم ايندول استيك اسيد اكسيداز (IAAO) در بافتهاى گياهى كه داراى رشد سريعى مىباشند، بسيار كم است ولى فعاليت اين آنزيم در شرايط تنش خشكى افزايش يافته و موجب تجزيه هورمون اكسين در كياه مى گردد. رزمجو و همكاران (Razmjoo et al., 2008)

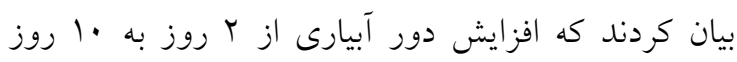
باعث كاهش معنىدار تعداد شاخه فرعى در كياه بابونه

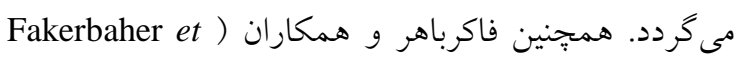

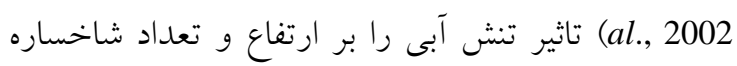

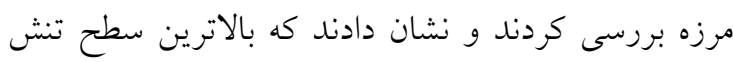
آبى، ارتفاع بوته و تعداد شاخساره مرزه را بطور معنىدارى برى بردي

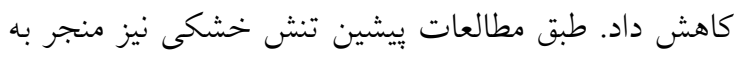
كاهش تعداد شاخئ فرعى در ريحان و بادرشبو شده است كه (Hassani and Omidbaigi, 2002; Safikhani, 2006) با نتايج اين آزمايش همخوانى دارد. اثر تنش خشكى بر عملكرد ميوه گشنيز در هر دو نسل

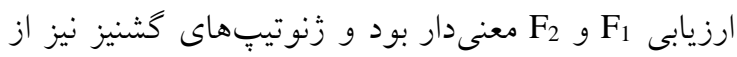

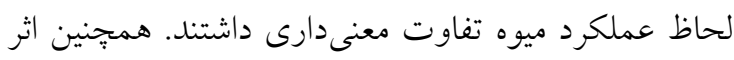
متقابل تنش خشكى و زنوتيبٍ براى اين صفت معنىدار بود (جدول (). در شرايط آبيارى معمولى بيشترين مقدار

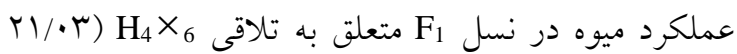


ميانخين مربعات تركيبقيذيرى خصوصى (SCA) بود

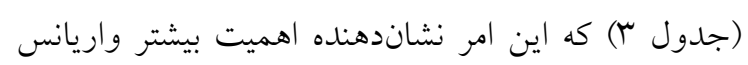

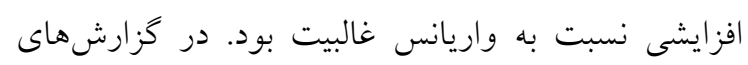

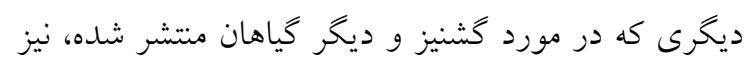
اهميت بيشتر واريانس افزايشى نسبت به واريانس غالبيت دورديز مشاهده مىشود ( Joshi et al., 2004; Sayar et al., 2007; Khodadadi et al., 2017 زن نشاندهنده وراثتيذيرى خصوصى بالا و اثر كمتر

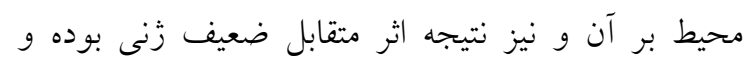

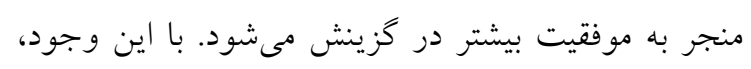

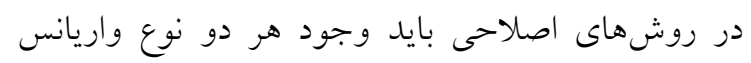
افزايشى و غالبيت را در نظر كرفت ( Topal et al., 2004). تركيبيذيرى خصوصى براى برخى از صفات

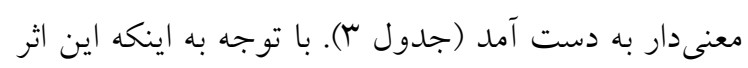

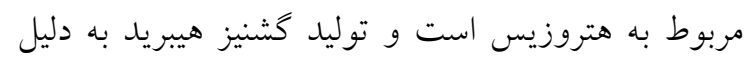
داشتن كلهاى ريز و مشكلات تكنيكى تلاقى دادن هنوز

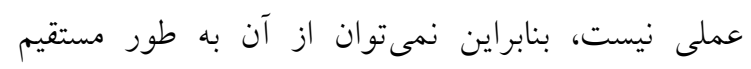

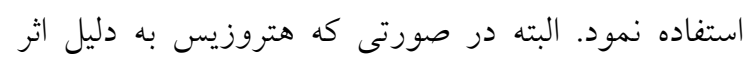
غالبيت زنها (تئورى غالبيت هتروزيس) و نه فوق غاليبت باشد، بدان معنى است كه مى توان دو والدى كه بيشترين

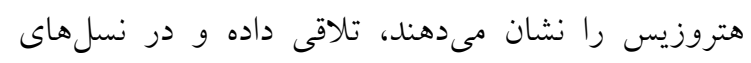

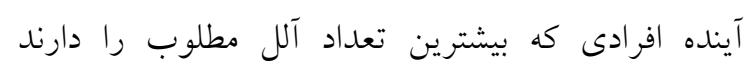

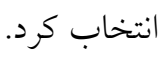

اجزاى زنتيكى برآورد شده براى صفات مورد مطالعه در

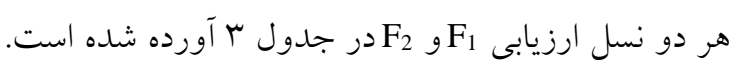

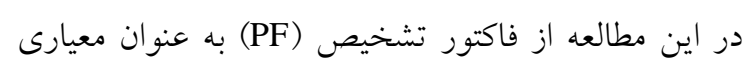

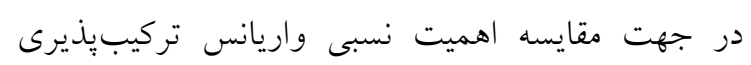

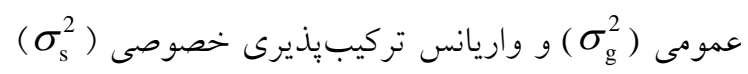

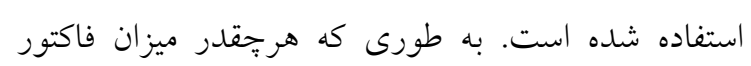
تشخيص به عدد يك نزديكتر باشد، بيانكر اهميت بيشتر

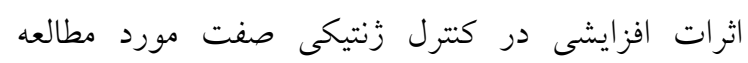
مىباشد. ميزان انحراف فاكتور تشخيص از عدد يكى بيانكر نقش بيشتر اثرات غالبيت در كنترل زنتيكى صفت مورد

\section{بر آورد بارامترهاى زنتيكى، تركيب بِيرى عمومى و خصوصى ...}

تنش ملايم بيشترين مقدار شاخص برداشت در هر دو

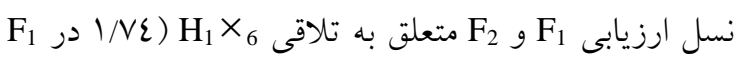

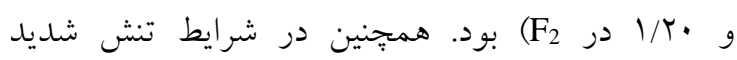

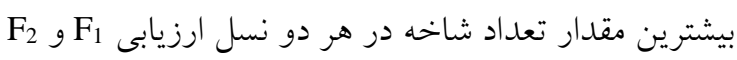
متعلق به تلاقى نتايج نشان داد كه تحت شرايط تنش ملايم بيشترين

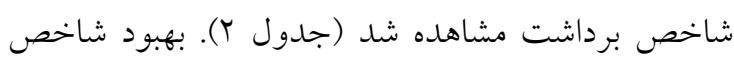
برداشت به يك افزايش ظرفيت فيزيولوزى فتوسنتز و

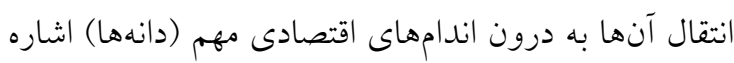
دارد (Golparvar et al., 2002). بنابر اين، افزايش عملكرد دانه از طريق تخصيص بيشتر مواد فتوسنتزى به مخازن

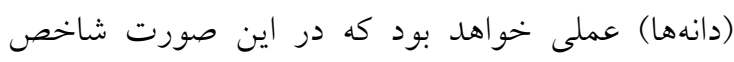
برداشت افزايش محسوسى خواهد داشت. به طور كلى،

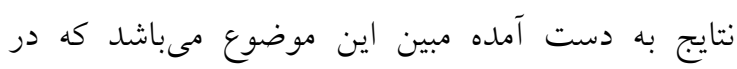

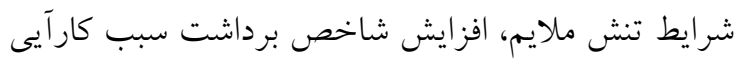

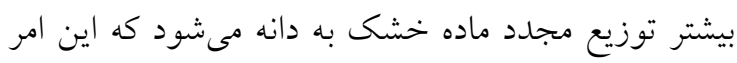

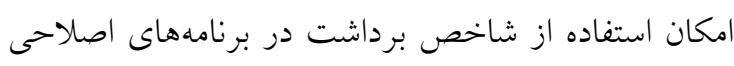
براى عملكرد دانه در شرايط تنش ملايم را امكانيذير بردي مى كند. در واقع در شرايط تنش ملايم كياه كشنيز ترجيح مىدهد كه انرزى خود را صرف عملكرد اقتصادى (ميوه) كند و عملكرد بيولوزيك كاهش مى يابد.

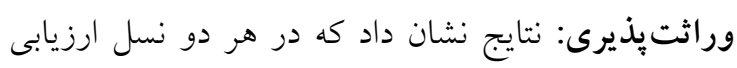
F و و در هر سه شرايط آبيارى مختلف، تركيبذيذيرى عمومى (GCA) براى همه صفات معنى دار به دست آمد سله

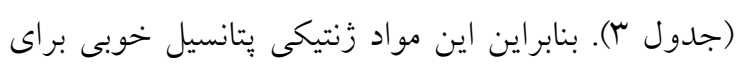

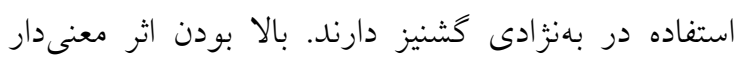
نشاندهنده اثر افزايشى زنها و احتمالاً اثر متقابل افزايشى در افزايشى است (Griffing, 1956). اين خصوصيت بيان كننده ميزان ارزش اصلاحى صفت است.

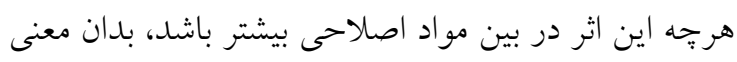

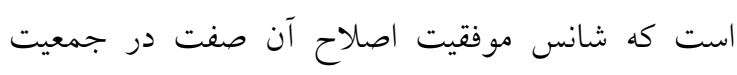
بيشتر است. در مورد همه صفات اندازهيرى شده،

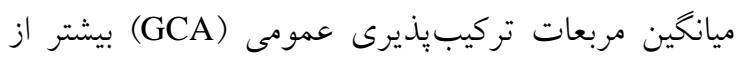


استفاده كرد. همجنين بهنظر ميرسد براى صفاتى كه توسط

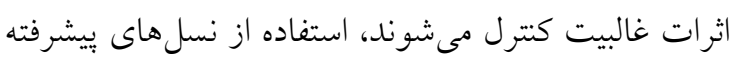
تلاقى سبب افزايش احتمال شكستن لينكازهاى زنى شود. مقدار وراثتيذيرى خصوصى براى صفت عملكرد ميوه

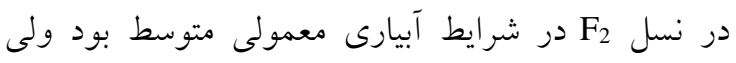
مقدار فاكتور تشخيص از 0/ • بيشتر بود كه بيانكر اين

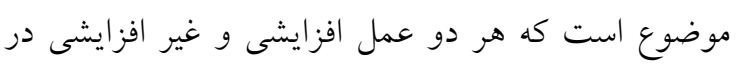

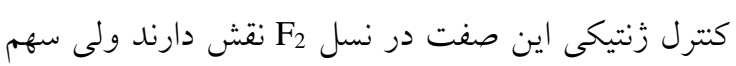
آثار افزايشى زنها بيشتر مىباشد. اخر كنترل زنتيكى يك صفت توسط هر دو اثر افزايشى و غير افزايشى زنها كتترل شود اما سهم آثار افزايشى زنه دنها

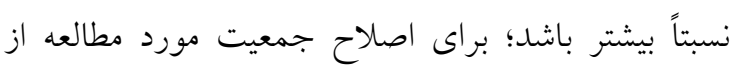
نظر اين صفت ابتدا بهتر است با انتخاب نتاج برتر از آثار

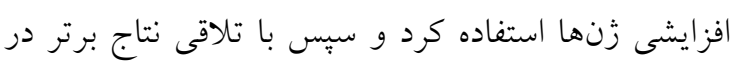
نسل هاى بالاتر از آثار غالبيت زنها نيز استفاده كرد.

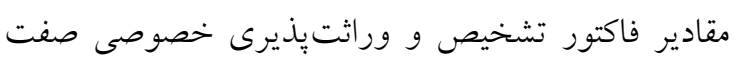

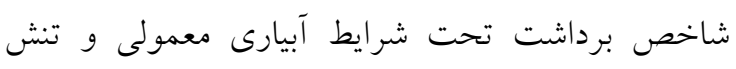

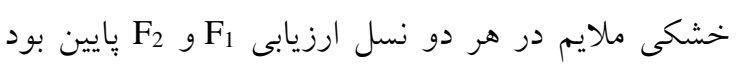

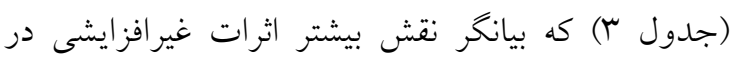
واريانس زنتيكى اين صفت در اين رزيمهاى آبيارى است.

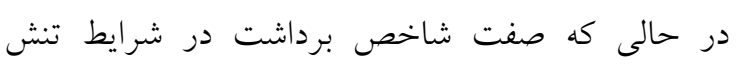
شديد از مقادير فاكتور تشخيص و و وراثتيذيرى

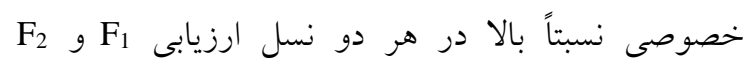
برخوردار بود (جدول ؟)، كه بيانگر نقش بيشتر اثرات

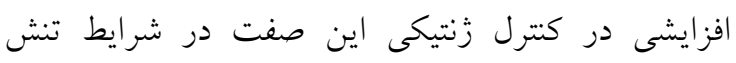

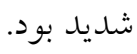

تركيبيذيرى عمومى و و خصوصى: برآوردهاى تركيبذيذبرى عمومى والدين براى صفات مختلف ارزيابى

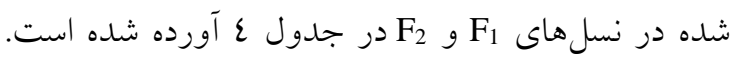
معنى دار بودن مقادير مثبت GCA براى برخى از والدين

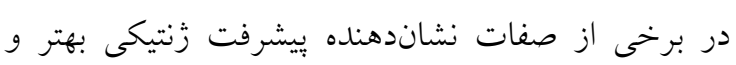

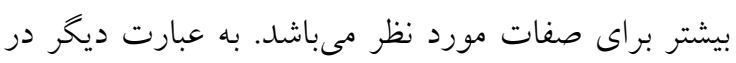

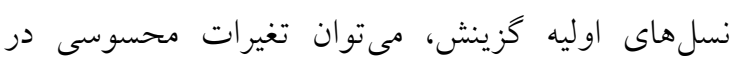

نظر مىباشد (Banerjee and Kole, 2009). مقادير فاكتور F⿸ تشخيص و وراثتيذيرى صفات در نسلهاى ارزيابى و F2 در جدول ب آورده شده است. در هر سه رزيم آبيارى مورد مطالعه، مقادير فاكتور تشخيص و وراثتيذيرى خصوصى صفات ارتفاع بوته، تعداد برى و عملكرد بيولوزيك در هر دو نسل ارزيابى وري

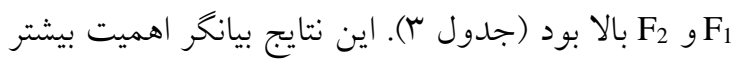

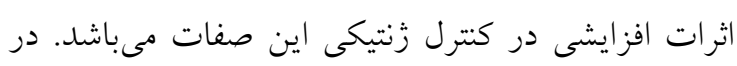
صفاتى كه اثرات افزايشى از اهميت بيشترى برخوردار است و وراثتيذيرى خصوصى بالاترى دارند، انتخاب تلاقىهاى برتر در نسلهاى اوليه درحال تفكيى F2 و و

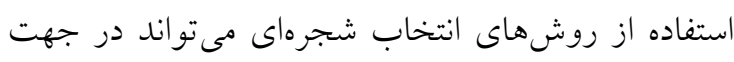

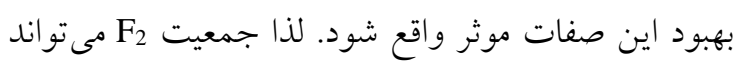
بعنوان يك جامعه مبنا در شروع برنامه اصلاحى بكار كرفته شود.

مقادير فاكتور تشخيص و وراثت بذيرى خصودى صفى صفت

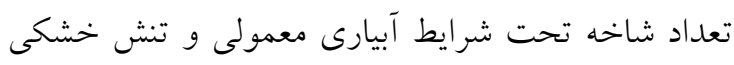

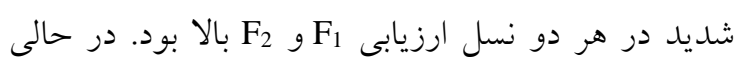
كه اين صفت در شرايط تنش ملايم از مقادير فاكتور تشخيص و وراثتيذيرى خصوصى متوسط در هر دو

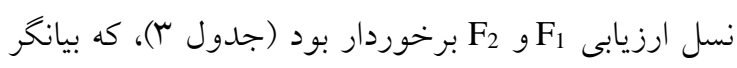
اهميت توام اثرات افزايشى و غالبيت در كتترل زنتيكى بردي صفت تعداد شاخه در شرايط تنش ملايم بود. اهميت توام

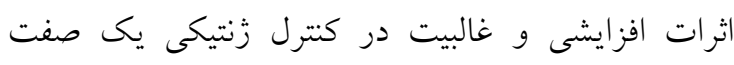

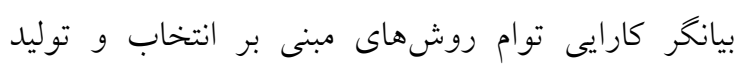
هيبريد در اصلاح اين صفت مىباشد. براى صفت عملكرد ميوه در نسل F1 مقادير فاكتور تشخيص و وراثتيذيرى خصوصى در هر سه رزيم آبيارى مورد مطالعه يايين بود (جدول بَ). مقادير فاكتور

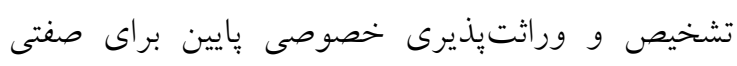

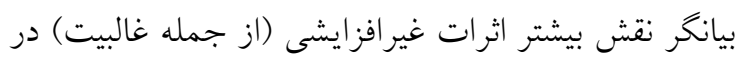
واريانس زنتيكى آن صفت است. بنابراين به منظور اصلاح عملكرد ميوه مىتوان از روشهاى مبنى بر توليد هيبريد 
براى كزينش زنوتيٍهاى با ارتفاع بالاى بوته جهت

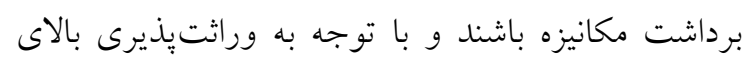

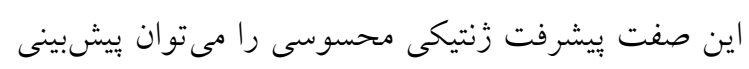
كرد. براى صفت تعداد برى در هر دو نسل ارزيابى Fi و

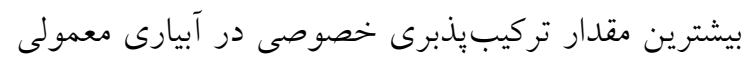

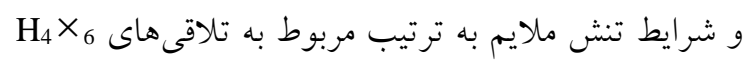

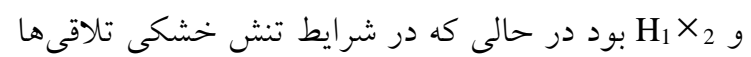
تركيبذيذيرى خصوصى مثبت و معنى دار براى صفت

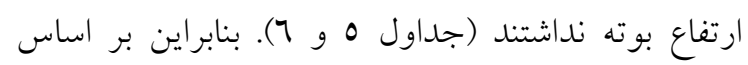

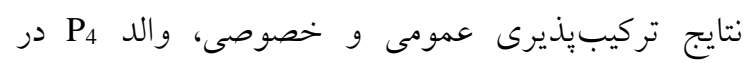

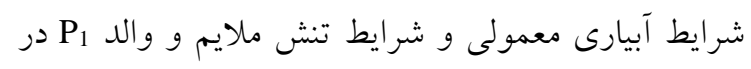

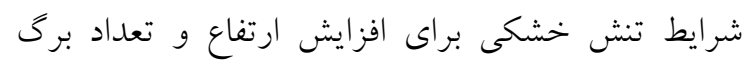

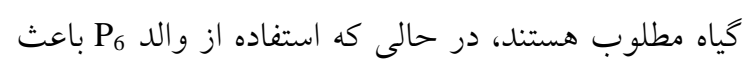

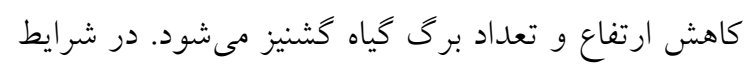
تنش خشكى، والد P6 بهترين كزينه براى اصلاح

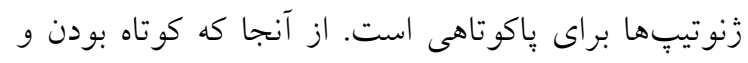

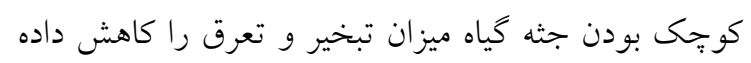

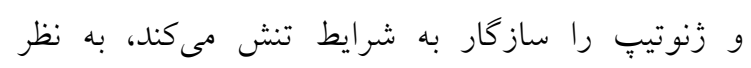

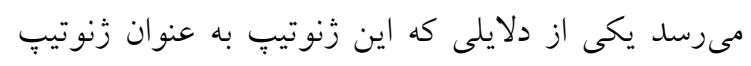
متحمل در اين تحقيق استفاده شد همين سازكارى باشد.

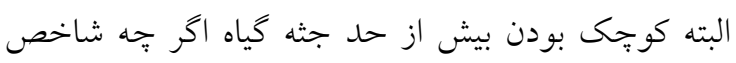
برداشت را بالا مىبرد ولى عملكرد نيز به دليل فتوسنتز كمتر و ميزان توليد كمتر كاهش شديد نشان مىدهد و وردي

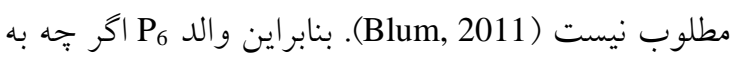
عنوان زنوتيب متحمل طبقهبندى مىشود، اما به دليل

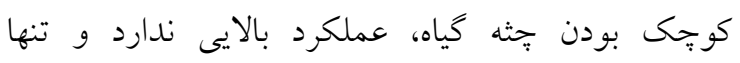

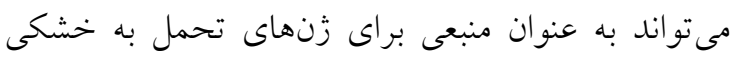

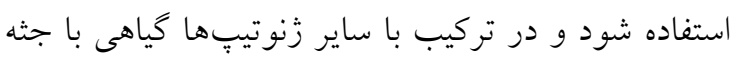

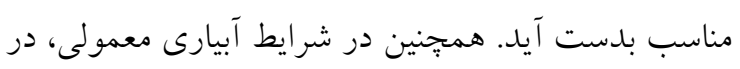

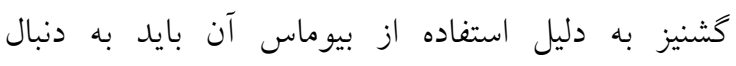

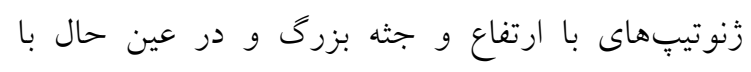

$$
\text { عملكرد ميوه مطلوب بود. }
$$

صفات مورد نظر كه GCA بالايى دارند انجام داد و از والدينى كه مقدار تركيبذيذيرى عمومى بالايى دارند

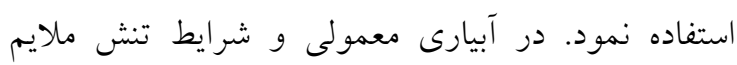
بيشترين تركيب يذيرى عمومى براى صفات ارتفاع بوته و

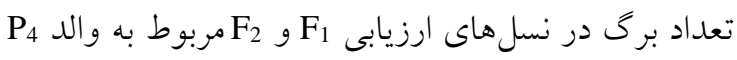
بود، در حالى كه در شرايط تنش خشكى بيشترين

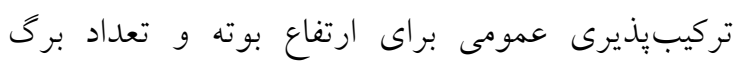
مربوط به والد P1 بود (جدول ع). كمترين تركيب بذيرى برى عمومى براى صفات ارتفاع بوته و تعداد برى در هر سه به به تردئ

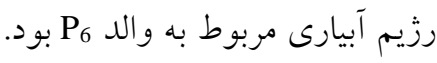

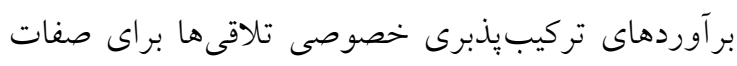

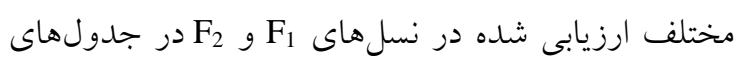

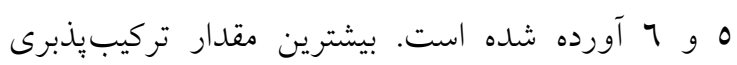
خصوصى براى صفت ارتفاع بوته در آبيارى معمولى و شرايط تنش ملايم در نسل F1 مربوط به تلاقى بـ بود، در حالى كه در شرايط تنش خشكى بيشترين تركيب يذبرى خصوصى براى صفت ارتفاع بوته مربوط به ديه

$$
\text { تلاقى }
$$

برآوردهاى تركيبرِذبرى خصوصى تلاقى ها براى صفات

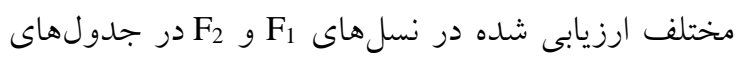

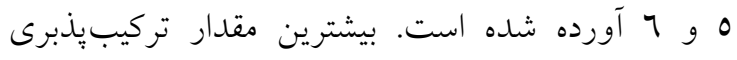
خصوصى براى صفت ارتفاع بوته در آبيارى معمولى و

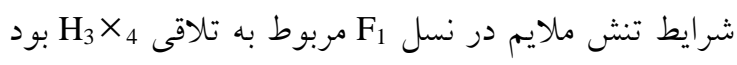
در حالى كه در شرايط تنش خشكى بنى بيشترين

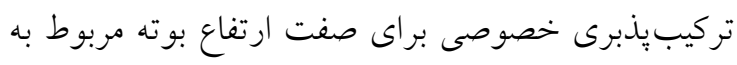

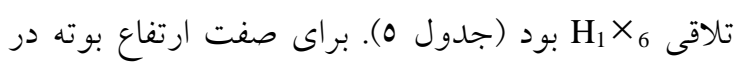

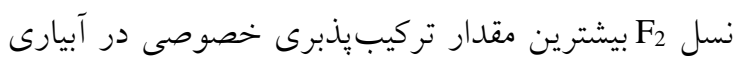

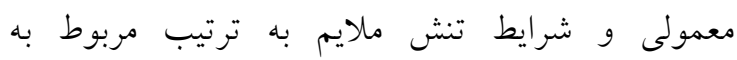
تلاقى هاى

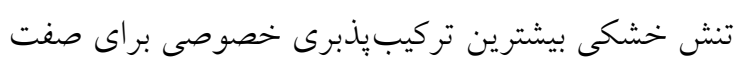

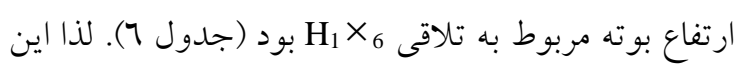

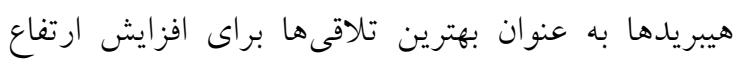

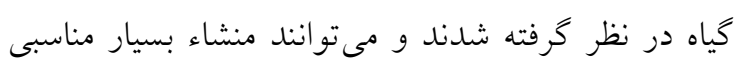




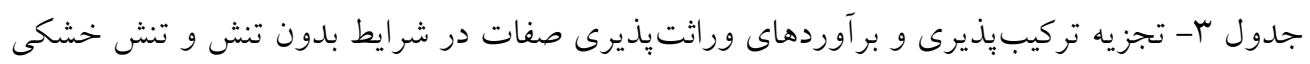

Table 3. Analysis of combining ability and heritability estimates of traits in non-stress and drought stress conditions

\begin{tabular}{|c|c|c|c|c|c|c|c|c|c|c|c|c|c|}
\hline \multirow{2}{*}{$\begin{array}{l}\text { Water } \\
\text { treatment }\end{array}$} & \multirow{2}{*}{ Estimate } & \multicolumn{2}{|c|}{ PH } & \multicolumn{2}{|c|}{$\mathrm{NL}$} & \multicolumn{2}{|c|}{$\mathrm{BN}$} & \multicolumn{2}{|c|}{ BY } & \multicolumn{2}{|c|}{ FY } & \multicolumn{2}{|c|}{$\mathrm{HI}$} \\
\hline & & $\mathrm{F}_{1}$ & $\mathrm{~F}_{2}$ & $\mathrm{~F}_{1}$ & $\mathrm{~F}_{2}$ & $\mathrm{~F}_{1}$ & $\mathrm{~F}_{2}$ & $\mathrm{~F}_{1}$ & $\mathrm{~F}_{2}$ & $\mathrm{~F}_{1}$ & $\mathrm{~F}_{2}$ & $\mathrm{~F}_{1}$ & $\mathrm{~F}_{2}$ \\
\hline \multirow{8}{*}{$\begin{array}{l}\text { Well } \\
\text { Watered }\end{array}$} & GCA & $260.74^{* *}$ & $196.26^{* *}$ & $22036.0^{* *}$ & $19944.34^{* * *}$ & $64.00^{* *}$ & $45.48^{* *}$ & $1147.35^{* *}$ & $930.89^{* *}$ & $167.36^{* * *}$ & $95.83^{* *}$ & $0.440^{* *}$ & $0.360^{* *}$ \\
\hline & SCA & $20.91^{* *}$ & $8.05^{\mathrm{ns}}$ & $2066.87^{* *}$ & $1506.64^{* *}$ & $7.69^{* *}$ & $3.60^{* *}$ & $129.35^{* *}$ & $97.48^{* * *}$ & $47.75^{* * *}$ & $15.91^{\text {** }}$ & $0.192^{* *}$ & $0.202^{* * *}$ \\
\hline & Error & 6.45 & 4.37 & 329.76 & 345.65 & 1.96 & 0.93 & 16.29 & 14.81 & 1.65 & 1.42 & 0.007 & 0.006 \\
\hline & $\sigma_{\mathrm{g}}^{2}$ & $9.99^{* * *}$ & $7.84^{* *}$ & $832.05^{* *}$ & $768.24^{* * *}$ & $2.35^{* *}$ & $1.75^{* *}$ & $42.42^{* *}$ & $34.73^{* *}$ & $4.98^{*}$ & $3.33^{* *}$ & $0.010^{\text {ns }}$ & $0.007^{\mathrm{ns}}$ \\
\hline & $\sigma_{\mathrm{s}}^{2}$ & $4.82^{* *}$ & $1.23^{\mathrm{ns}}$ & $579.04^{* *}$ & $387.00^{* * *}$ & $1.91^{* *}$ & $0.89^{* *}$ & $37.69^{* *}$ & $27.56^{* *}$ & $15.37^{* *}$ & $4.83^{* *}$ & $0.062^{* *}$ & $0.065^{* *}$ \\
\hline & $\mathrm{h}_{\mathrm{B}}^{2}$ & 0.92 & 0.94 & 0.95 & 0.96 & 0.91 & 0.95 & 0.96 & 0.97 & 0.98 & 0.97 & 0.97 & 0.99 \\
\hline & $\mathrm{h}_{\mathrm{N}}^{2}$ & 0.74 & 0.85 & 0.71 & 0.72 & 0.65 & 0.71 & 0.66 & 0.63 & 0.38 & 0.49 & 0.24 & 0.14 \\
\hline & PF & 0.81 & 0.93 & 0.74 & 0.80 & 0.71 & 0.80 & 0.69 & 0.72 & 0.39 & 0.58 & 0.25 & 0.17 \\
\hline \multirow{8}{*}{$\begin{array}{l}\text { Moderate } \\
\text { Water } \\
\text { Stress }\end{array}$} & GCA & $342.51^{* *}$ & $315.92^{* *}$ & $2841.38^{* *}$ & $2553.70^{* * *}$ & $20.01^{* *}$ & $14.90^{* * *}$ & $134.06^{* *}$ & $120.12^{* * *}$ & $88.09^{* *}$ & $57.49^{* *}$ & $1.73^{* *}$ & $1.022^{* * *}$ \\
\hline & SCA & $28.83^{* *}$ & $17.77^{* *}$ & $145.92^{* *}$ & $86.01^{* *}$ & $5.20^{* *}$ & $2.41^{* * *}$ & $5.77^{* *}$ & $4.02^{\mathrm{ns}}$ & $35.04^{* *}$ & $16.39^{* *}$ & $0.58^{* *}$ & $0.239^{* * *}$ \\
\hline & Error & 9.01 & 4.71 & 37.15 & 28.43 & 1.34 & 0.90 & 2.69 & 2.56 & $0.90^{* * *}$ & 1.14 & 0.03 & 0.041 \\
\hline & $\sigma_{\mathrm{g}}^{2}$ & $13.07^{* *}$ & $12.42^{* *}$ & $112.31^{* *}$ & $102.82^{* *}$ & $0.62^{*}$ & $0.52^{* *}$ & $5.35^{* *}$ & $4.84^{* *}$ & $2.21^{\mathrm{ns}}$ & $1.71^{*}$ & $0.05^{*}$ & $0.033^{* *}$ \\
\hline & $\sigma_{\mathrm{s}}^{2}$ & $6.60^{* *}$ & $4.35^{* *}$ & $36.25^{* *}$ & $19.19^{* *}$ & $1.29^{* *}$ & $0.51^{* *}$ & $1.02^{*}$ & $0.49^{\text {ns }}$ & $11.38^{* *}$ & $5.08^{* *}$ & $0.18^{* *}$ & $0.066^{* *}$ \\
\hline & $\mathrm{h}_{\mathrm{B}}^{2}$ & 0.92 & 0.96 & 0.95 & 0.97 & 0.85 & 0.88 & 0.93 & 0.94 & 0.98 & 0.97 & 0.97 & 0.94 \\
\hline & $\mathrm{h}_{\mathrm{N}}^{2}$ & 0.73 & 0.78 & 0.82 & 0.86 & 0.42 & 0.53 & 0.85 & 0.88 & 0.27 & 0.33 & 0.34 & 0.40 \\
\hline & $\mathrm{PF}$ & 0.80 & 0.85 & 0.86 & 0.91 & 0.49 & 0.67 & 0.91 & 0.95 & 0.28 & 0.40 & 0.34 & 0.50 \\
\hline \multirow{8}{*}{$\begin{array}{l}\text { Sever } \\
\text { Water } \\
\text { Stress }\end{array}$} & GCA & $177.46^{* *}$ & $158.88^{* * *}$ & $633.46^{* *}$ & $518.80^{* * *}$ & $9.95^{* *}$ & $10.62^{* *}$ & $14.40^{* *}$ & $13.93^{* *}$ & $20.98^{* *}$ & $15.76^{* *}$ & $0.98^{* *}$ & $0.827^{* * *}$ \\
\hline & SCA & $16.51^{* *}$ & $12.81^{* *}$ & $67.49^{\text {ns }}$ & $35.75^{\text {ns }}$ & $0.83^{\mathrm{ns}}$ & $0.40^{\mathrm{ns}}$ & $1.44^{\mathrm{ns}}$ & $1.25^{\mathrm{ns}}$ & $7.91^{* * *}$ & $4.93^{* *}$ & $0.16^{* *}$ & $0.105^{* * *}$ \\
\hline & Error & 4.80 & 3.82 & 49.99 & 33.80 & 0.45 & 0.25 & 1.05 & 0.82 & 0.80 & 0.75 & 0.02 & 0.028 \\
\hline & $\sigma_{\mathrm{g}}^{2}$ & $6.71^{* *}$ & $6.09^{* *}$ & $23.58^{* *}$ & $20.13^{* *}$ & $0.38^{* *}$ & $0.43^{* *}$ & $0.54^{* *}$ & $0.53^{* *}$ & $0.54^{\mathrm{ns}}$ & $0.45^{*}$ & $0.03^{* *}$ & $0.030^{* *}$ \\
\hline & $\sigma_{\mathrm{s}}^{2}$ & $3.90^{* *}$ & $3.00^{* *}$ & $5.83^{\mathrm{ns}}$ & $0.65^{\mathrm{ns}}$ & $0.13^{\text {ns }}$ & $0.05^{\mathrm{ns}}$ & $0.13^{\text {ns }}$ & $0.14^{\mathrm{ns}}$ & $2.37^{* *}$ & $1.39^{* *}$ & $0.05^{* *}$ & $0.026^{* * *}$ \\
\hline & $\mathrm{h}_{\mathrm{B}}^{2}$ & 0.92 & 0.94 & 0.76 & 0.83 & 0.86 & 0.94 & 0.78 & 0.86 & 0.93 & 0.93 & 0.94 & 0.93 \\
\hline & $\mathrm{h}_{\mathrm{N}}^{2}$ & 0.71 & 0.71 & 0.68 & 0.81 & 0.73 & 0.87 & 0.69 & 0.73 & 0.29 & 0.32 & 0.51 & 0.59 \\
\hline & PF & 0.77 & 0.80 & 0.89 & 0.98 & 0.86 & 0.94 & 0.89 & 0.88 & 0.31 & 0.39 & 0.59 & 0.70 \\
\hline
\end{tabular}

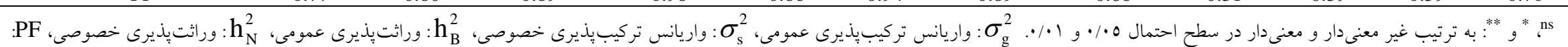

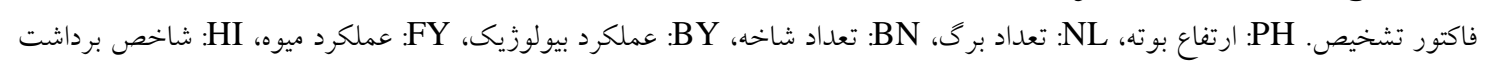

ns,${ }^{*}$ and ${ }^{* *}$ : non-significant \& significant at the $0.05 \& 0.01$, respectively. Variance of general combining ability $\left(\sigma_{\mathrm{g}}^{2}\right)$, variance of specific combining ability $\left(\sigma_{\mathrm{s}}^{2}\right)$, PF: prediction factor. Plant height (PH), number of leaf (NL), branch number (BN), biological yield (BY), fruit yield (FY), harvest index (HI) 
كمترين تركيبذيذيرى عمومى براى عملكرد ميوه در هر

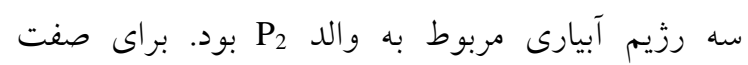

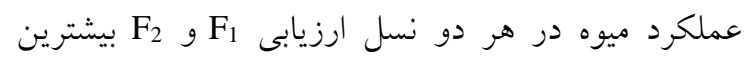

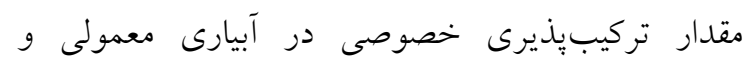

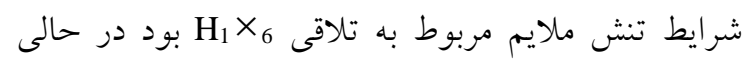

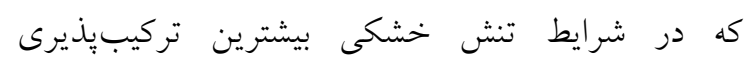

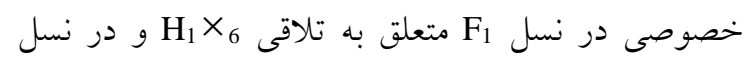
Fتعلق به تلاقى $F_{2}$ والد Pر شر در ايط آبيارى معمولى و شر ايط تنش ملايم و والد Po در شرايط تنش خشكى براى افزايش عملكرد

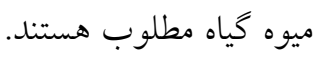

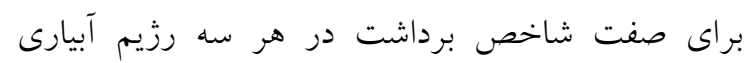

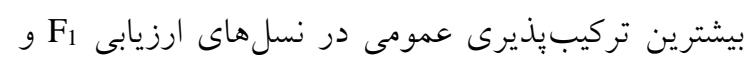

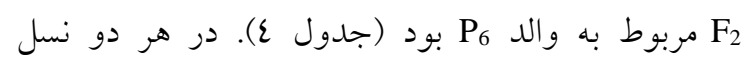
ارزيابى F⿸ F و F⿸ بيشترين مقدار تركيبذيذيرى خصوصى شاخص برداشت در آبيارى معمولى و شرايط تنش ملايم به ترتيب مربوط به تلاقى

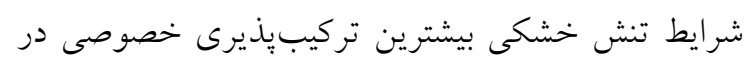

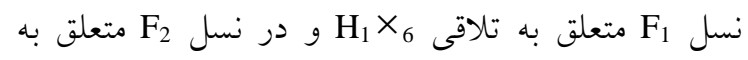

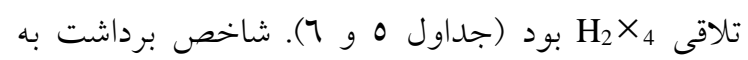

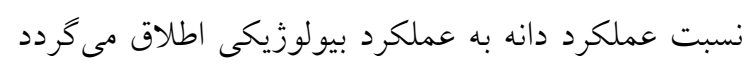
(Donald and Hamblin, 1976) مواد حاصل از فتوسنتز به دانهها را نشان مىدهد. بالا توان بودن شاخص برداشت به اين معنى است كه سهم دانهها

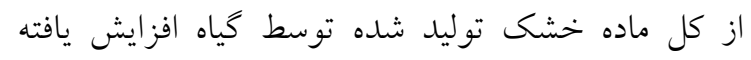

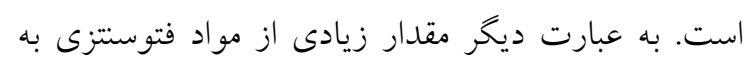

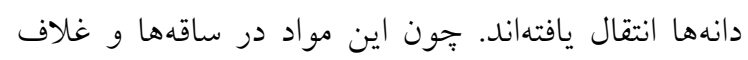

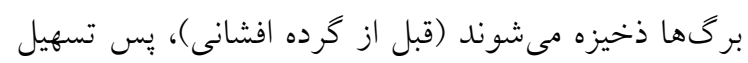

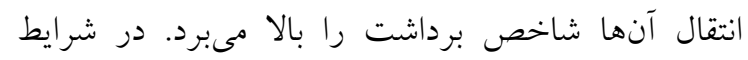

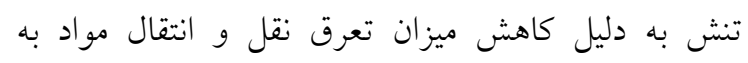

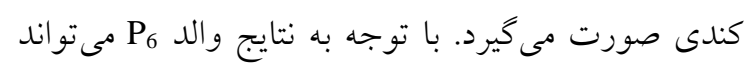

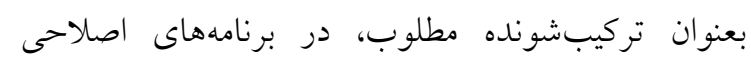
افزايش شاخص برداشت كشنيز استفاده شود.
بنابراين بر اساس نتايج تركيبيذيرى عمومى و خصوصى، والد P4 در شرايط آبيارى معمولى براى افزايش ارتفاع و تعداد برى گياه (جثه كياه) مطلوب است.

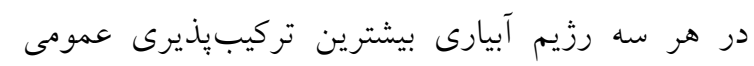

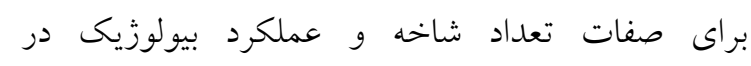

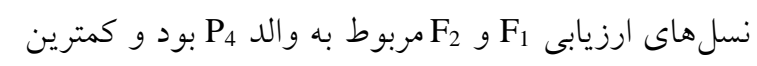
تركيبيذيرى عمومى براى اين صفات در هر سه رزيم

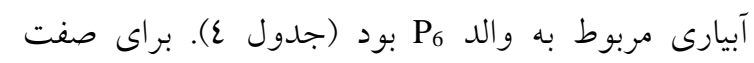

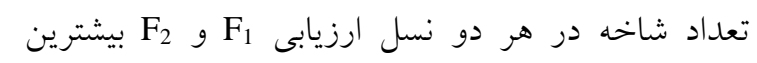

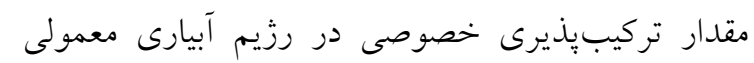

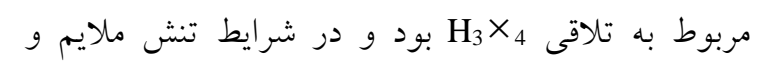

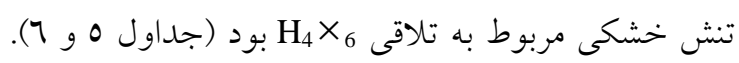
همجنين بيشترين مقدار تركيبذيذيرى خصوصى براى بر بـ

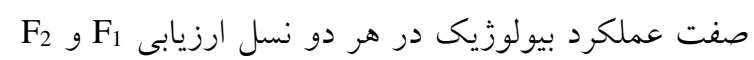

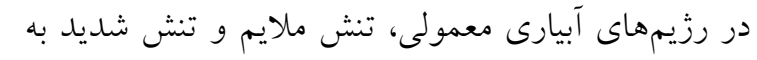
ترتيب مربوط به تلاقى ها

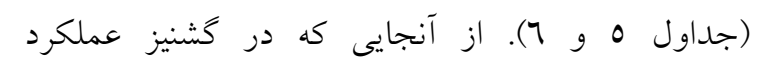

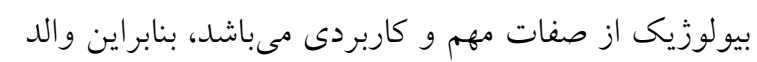
مى Pواند بعنوان تركيبشونده مطلوب، در برنامههاى

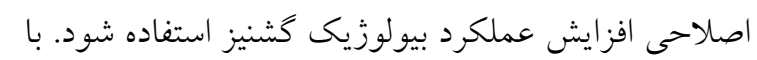
توجه به SCA مثبت و معنى دار هيبريدهاى

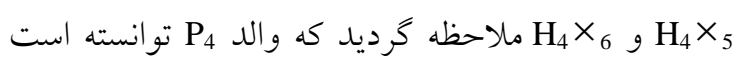
در انتقال تعداد شاخه و عملكرد بيولوزيك بالا به نتاج موفق عمل كند. اين هيبريدها مىتواند منشاء كزينش

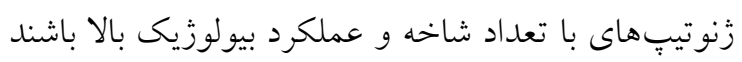
و با توجه به افزايشى بودن كتترل زنتيكى و وراثت بذإيرى

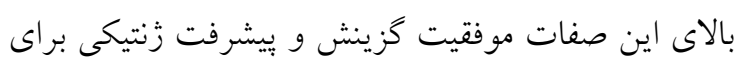
صفات مذكور قابل بيشبينى خواهد بود.

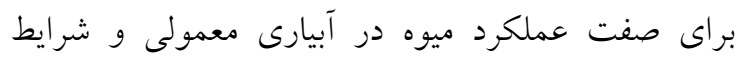
تنش ملايم بيشترين تركيبزئيرى عمومى در نسلهاى

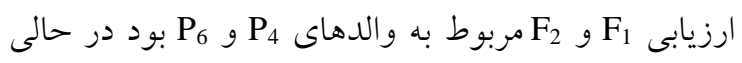
كه در شرايط تنش خشكى بيشترين تركيبِيذيرى عمومى

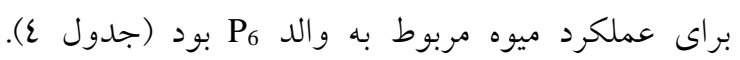


جدول ع- برآورد تركيب يذيرى عمومى والدين در نسل هاى F⿸ و F براى صفات در شرايط بدون تنش و تنش خشكى

Table 4. Estimation of general combining ability of the parents in $\mathrm{F}_{1}$ and $\mathrm{F}_{2}$ under non-stress and drought stress conditions

\begin{tabular}{|c|c|c|c|c|c|c|c|c|c|c|c|c|c|}
\hline \multirow{2}{*}{$\begin{array}{c}\text { Water } \\
\text { treatment }\end{array}$} & \multirow{2}{*}{ Parent } & \multicolumn{2}{|c|}{$\mathrm{PH}$} & \multicolumn{2}{|c|}{ NL } & \multicolumn{2}{|c|}{$\mathrm{BN}$} & \multicolumn{2}{|c|}{ BY } & \multicolumn{2}{|c|}{ FY } & \multicolumn{2}{|c|}{$\mathrm{HI}$} \\
\hline & & $F_{1}$ & $\mathrm{~F}_{2}$ & $F_{1}$ & $\mathrm{~F}_{2}$ & $F_{1}$ & $\mathrm{~F}_{2}$ & $F_{1}$ & $\mathrm{~F}_{2}$ & $F_{1}$ & $\mathrm{~F}_{2}$ & $\mathrm{~F}_{1}$ & $\mathrm{~F}_{2}$ \\
\hline \multirow{8}{*}{$\begin{array}{l}\text { Well } \\
\text { Watered }\end{array}$} & $\mathrm{P}_{1}$ & $-0.44^{\mathrm{ns}}$ & $-0.46^{\text {ns }}$ & $12.12^{* *}$ & $15.06^{* *}$ & $0.28^{\mathrm{ns}}$ & $0.43^{*}$ & $3.20^{* *}$ & $3.53^{* *}$ & $0.90^{* *}$ & $0.92^{\text {** }}$ & $-0.055^{* *}$ & $-0.065^{\text {*** }}$ \\
\hline & $\mathrm{P}_{2}$ & $-0.87^{\mathrm{ns}}$ & $-0.82^{*}$ & $-10.49^{* *}$ & $-8.53^{*}$ & $0.12^{\mathrm{ns}}$ & $0.02^{\mathrm{ns}}$ & $-4.08^{* *}$ & $-3.80^{* * *}$ & $-2.55^{* *}$ & $-1.98^{* *}$ & $-0.032^{\text {ns }}$ & $-0.033^{*}$ \\
\hline & $\mathrm{P}_{3}$ & $-0.14^{\mathrm{ns}}$ & $0.42^{\mathrm{ns}}$ & $-19.37^{* *}$ & $-21.37^{* *}$ & $-0.78^{* *}$ & $-0.64^{* *}$ & $-4.60^{* *}$ & $-4.47^{* *}$ & $-2.28^{* *}$ & $-1.80^{* * *}$ & $-0.005^{\text {ns }}$ & $0.028^{\text {ns }}$ \\
\hline & $\mathrm{P}_{4}$ & $5.40^{* * *}$ & $4.53^{* *}$ & $56.23^{* *}$ & $51.64^{* *}$ & $2.86^{* *}$ & $2.28^{* *}$ & $12.70^{* *}$ & $11.15^{* *}$ & $3.69^{* *}$ & $2.82^{* *}$ & $-0.106^{* *}$ & $-0.097^{* *}$ \\
\hline & $\mathrm{P}_{5}$ & $0.89^{\text {ns }}$ & $0.68^{\text {ns }}$ & $-13.96^{* *}$ & $-13.14^{* *}$ & $-0.41^{\mathrm{ns}}$ & $-0.19^{\text {ns }}$ & $-2.23^{* *}$ & $-2.18^{* *}$ & $-1.97^{* *}$ & $-1.39^{* *}$ & $-0.070^{* *}$ & $-0.068^{* * *}$ \\
\hline & $\mathrm{P}_{6}$ & $-4.83^{* *}$ & $-4.34^{* *}$ & $-24.54^{* *}$ & $-23.66^{* *}$ & $-2.07^{* *}$ & $-1.90^{* *}$ & $-4.99^{* *}$ & $-4.23^{* *}$ & $2.21^{* *}$ & $1.43^{* *}$ & $0.268^{* *}$ & $0.234^{* * *}$ \\
\hline & LSD (gi) & 0.96 & 0.79 & 6.84 & 7.00 & 0.53 & 0.36 & 1.52 & 1.45 & 0.48 & 0.45 & 0.031 & 0.030 \\
\hline & LSD (gi-gj) & 1.48 & 1.22 & 10.59 & 10.85 & 0.82 & 0.56 & 2.35 & 2.24 & 0.75 & 0.70 & 0.048 & 0.046 \\
\hline \multirow{7}{*}{$\begin{array}{l}\text { Moderate } \\
\text { Water } \\
\text { Stress }\end{array}$} & $\mathrm{P}_{2}$ & $-0.66^{\mathrm{ns}}$ & $-0.09^{\text {ns }}$ & $1.76^{\mathrm{ns}}$ & $0.93^{\mathrm{ns}}$ & $0.14^{\mathrm{ns}}$ & $0.041^{\mathrm{ns}}$ & $-0.92^{* *}$ & $-0.80^{* *}$ & $-1.54^{* *}$ & $-1.26^{* *}$ & $-0.159^{* *}$ & $-0.12^{* * *}$ \\
\hline & $\mathrm{P}_{3}$ & $0.73^{\text {ns }}$ & $-0.03^{\text {ns }}$ & $-3.73^{* *}$ & $-2.93^{* *}$ & $-0.74^{* *}$ & $-0.585^{* *}$ & $-0.86^{* *}$ & $-0.83^{* *}$ & $-1.09^{* *}$ & $-0.72^{* * *}$ & $-0.084^{*}$ & $-0.04^{\mathrm{ns}}$ \\
\hline & $\mathrm{P}_{4}$ & $3.23^{\text {** }}$ & $3.90^{* *}$ & $13.98^{* *}$ & $13.65^{* *}$ & $1.55^{* *}$ & $1.209^{* *}$ & $4.42^{\text {*** }}$ & $4.14^{* *}$ & $2.47^{* *}$ & $2.20^{* * *}$ & $-0.047^{\text {ns }}$ & $-0.01^{\mathrm{ns}}$ \\
\hline & $\mathrm{P}_{5}$ & $2.38^{\text {** }}$ & $1.31^{* * *}$ & $-0.65^{\mathrm{ns}}$ & $-0.09^{\mathrm{ns}}$ & $-0.56^{* *}$ & $0.004^{\mathrm{ns}}$ & $-0.98^{* *}$ & $-0.88^{* *}$ & $-1.37^{* *}$ & $-1.31^{* *}$ & $-0.119^{* *}$ & $-0.13^{* *}$ \\
\hline & $\mathrm{P}_{6}$ & $-7.21^{\text {*** }}$ & $-6.79^{* *}$ & $-18.22^{* *}$ & $-17.39^{* *}$ & $-0.83^{* *}$ & $-1.068^{* *}$ & $-2.33^{* *}$ & $-2.31^{* *}$ & $2.45^{* *}$ & $1.72^{\text {** }}$ & $0.542^{* *}$ & $0.41^{* *}$ \\
\hline & LSD (gi) & 1.13 & 0.82 & 2.30 & 2.01 & 0.44 & 0.36 & 0.62 & 0.60 & 0.36 & 0.40 & 0.069 & 0.08 \\
\hline & LSD (gi-gj) & 1.75 & 1.27 & 3.56 & 3.11 & 0.67 & 0.55 & 0.96 & 0.93 & 0.55 & 0.62 & 0.107 & 0.12 \\
\hline \multirow{7}{*}{$\begin{array}{l}\text { Sever } \\
\text { Water } \\
\text { Stress }\end{array}$} & $\mathrm{P}_{1}$ & $2.90^{* * *}$ & $2.85^{* *}$ & $6.94^{* * *}$ & $4.73^{* * *}$ & $0.59^{* * *}$ & $0.59^{* *}$ & $0.30^{\mathrm{ns}}$ & $0.33^{\text {ns }}$ & $-0.50^{*}$ & $-0.52^{*}$ & $-0.11^{* *}$ & $-0.12^{* * *}$ \\
\hline & $\mathrm{P}_{2}$ & $-0.63^{\mathrm{ns}}$ & $-0.12^{\mathrm{ns}}$ & $0.14^{\mathrm{ns}}$ & $0.73^{\text {ns }}$ & $0.20^{\mathrm{ns}}$ & $0.10^{\mathrm{ns}}$ & $-0.39^{*}$ & $-0.35^{*}$ & $-0.89^{* *}$ & $-0.67^{* *}$ & $-0.14^{* *}$ & $-0.11^{* *}$ \\
\hline & $\mathrm{P}_{4}$ & $0.82^{\text {ns }}$ & $0.69^{\text {ns }}$ & $-2.11^{\mathrm{ns}}$ & $-1.34^{\mathrm{ns}}$ & $0.64^{* *}$ & $0.62^{* *}$ & $1.06^{* *}$ & $0.97^{* *}$ & $0.88^{* *}$ & $0.77^{* *}$ & $0.07^{*}$ & $0.06^{\mathrm{ns}}$ \\
\hline & $\mathrm{P}_{5}$ & $1.02^{*}$ & $1.28^{* * *}$ & $4.29^{* *}$ & $4.54^{* *}$ & $0.02^{\mathrm{ns}}$ & $0.11^{\mathrm{ns}}$ & $0.44^{*}$ & $0.50^{* *}$ & $-0.68^{* *}$ & $-0.65^{* *}$ & $-0.16^{* *}$ & $-0.15^{\text {** }}$ \\
\hline & $\mathrm{P}_{6}$ & $-5.06^{* * *}$ & $-4.78^{* *}$ & $-7.64^{* *}$ & $-7.88^{* *}$ & $-1.06^{* *}$ & $-1.18^{* *}$ & $-1.19^{* *}$ & $-1.20^{* *}$ & $1.43^{* *}$ & $1.23^{\text {** }}$ & $0.37^{* *}$ & $0.34^{* *}$ \\
\hline & LSD (gi) & 0.83 & 0.74 & 2.66 & 2.19 & 0.25 & 0.19 & 0.39 & 0.34 & 0.34 & 0.33 & 0.05 & 0.06 \\
\hline & LSD (gi-gj) & 1.28 & 1.14 & 4.13 & 3.39 & 0.39 & 0.29 & 0.60 & 0.53 & 0.52 & 0.51 & 0.08 & 0.10 \\
\hline
\end{tabular}

ns, * and ${ }^{* *}$ : non-significant \& significant at the $0.05 \& 0.01$ probability level, respectively. Plant height (PH), number of leaf (NL), branch number (BN), biological yield (BY), fruit yield (FY), harvest index (HI) 


$$
\text { جدول ه- برآورد تركيبِيذيرى خصوصى تلاقى ها در نسل F1 براى صفات در شرايط بدون تنش و تنش خشكى }
$$

Table 5. Estimation of specific combining ability of the crosses in F1 generation under non-stress and drought

\begin{tabular}{|c|c|c|c|c|c|c|c|}
\hline \multicolumn{8}{|c|}{ stress conditions } \\
\hline Water treatment & $\mathrm{F}_{1 \mathrm{~S}}$ & $\mathrm{PH}$ & $\mathrm{LN}$ & $\mathrm{BN}$ & BY & $\mathrm{FY}$ & HI \\
\hline \multirow{18}{*}{ Well Watered } & $\mathrm{H}_{1} \times{ }_{2}$ & $-0.005^{\mathrm{ns}}$ & $26.29^{* *}$ & $0.41^{\mathrm{ns}}$ & $0.91^{\mathrm{ns}}$ & $-1.18^{\mathrm{ns}}$ & $-0.09^{\mathrm{ns}}$ \\
\hline & $\mathrm{H}_{1} \times{ }_{3}$ & $-1.030^{\mathrm{ns}}$ & $-15.33^{\mathrm{ns}}$ & $-0.56^{\mathrm{ns}}$ & $3.10^{\mathrm{ns}}$ & $-0.02^{\mathrm{ns}}$ & $-0.08^{\mathrm{ns}}$ \\
\hline & $\mathrm{H}_{1} \times{ }_{4}$ & $1.691^{\mathrm{ns}}$ & $-0.83^{\mathrm{ns}}$ & $1.77^{*}$ & $5.81^{* *}$ & $4.09^{* *}$ & $0.08^{\mathrm{ns}}$ \\
\hline & $\mathrm{H}_{1} \times{ }_{5}$ & $-1.092^{\mathrm{ns}}$ & $-9.80^{\mathrm{ns}}$ & $-0.46^{\mathrm{ns}}$ & $2.40^{\mathrm{ns}}$ & $-0.78^{\mathrm{ns}}$ & $-0.06^{\mathrm{ns}}$ \\
\hline & $\mathrm{H}_{1} \times{ }_{6}$ & $1.162^{\mathrm{ns}}$ & $29.84^{* *}$ & $-1.00^{\mathrm{ns}}$ & $1.16^{\mathrm{ns}}$ & $4.56^{* *}$ & $0.08^{\mathrm{ns}}$ \\
\hline & $\mathrm{H}_{2} \times 3$ & $-2.371^{\mathrm{ns}}$ & $-2.59^{\mathrm{ns}}$ & $-1.29^{\mathrm{ns}}$ & $-3.46^{\mathrm{ns}}$ & $-0.99^{\mathrm{ns}}$ & $-0.04^{\mathrm{ns}}$ \\
\hline & $\mathrm{H}_{2} \times{ }_{4}$ & $2.449^{\mathrm{ns}}$ & $13.21^{\mathrm{ns}}$ & $0.40^{\mathrm{ns}}$ & $6.75^{* * *}$ & $0.87^{\mathrm{ns}}$ & $-0.05^{\mathrm{ns}}$ \\
\hline & $\mathrm{H}_{2} \times 5$ & $0.333^{\mathrm{ns}}$ & $-3.43^{\mathrm{ns}}$ & $0.07^{\mathrm{ns}}$ & $-2.90^{\mathrm{ns}}$ & $-1.20^{\mathrm{ns}}$ & $-0.05^{\mathrm{ns}}$ \\
\hline & $\mathrm{H}_{2} \times 6$ & $0.220^{\mathrm{ns}}$ & $-17.02^{\mathrm{ns}}$ & $-0.01^{\mathrm{ns}}$ & $-3.93^{\mathrm{ns}}$ & $3.05^{* *}$ & $0.48^{* *}$ \\
\hline & $\mathrm{H}_{3} \times{ }_{4}$ & $5.391^{* *}$ & $3.86^{\mathrm{ns}}$ & $3.16^{* *}$ & $6.94^{* *}$ & $2.81^{* *}$ & $-0.01^{\mathrm{ns}}$ \\
\hline & $\mathrm{H}_{3} \times{ }_{5}$ & $0.274^{\mathrm{ns}}$ & $19.89^{*}$ & $-0.80^{\mathrm{ns}}$ & $-1.98^{\mathrm{ns}}$ & $-1.39^{\mathrm{ns}}$ & $-0.09^{\mathrm{ns}}$ \\
\hline & $\mathrm{H}_{3} \times 6$ & $-0.205^{\mathrm{ns}}$ & $-2.97^{\mathrm{ns}}$ & $-1.24^{\mathrm{ns}}$ & $-4.54^{*}$ & $1.79^{*}$ & $0.49^{* *}$ \\
\hline & $\mathrm{H}_{4} \times{ }_{5}$ & $3.362^{* *}$ & $24.79^{* *}$ & $1.33^{\mathrm{ns}}$ & $7.56^{* *}$ & $3.30^{* *}$ & $0.04^{\mathrm{ns}}$ \\
\hline & $\mathrm{H}_{4} \times{ }_{6}$ & $-4.584^{* *}$ & $56.90^{* *}$ & $0.78^{\mathrm{ns}}$ & $6.66^{* *}$ & $4.25^{* *}$ & $-0.13^{* *}$ \\
\hline & $\mathrm{H}_{5} \times{ }_{6}$ & $-0.834^{\mathrm{ns}}$ & $-13.48^{\mathrm{ns}}$ & $-1.14^{\mathrm{ns}}$ & $-2.25^{\mathrm{ns}}$ & $2.54^{* *}$ & $0.23^{* *}$ \\
\hline & LSD (sij) & 2.63 & 18.78 & 1.45 & 4.17 & 1.33 & 0.09 \\
\hline & LSD (sij-sik) & 3.92 & 28.03 & 2.16 & 6.23 & 1.99 & 0.13 \\
\hline & LSD (sij-skl) & 3.63 & 25.95 & 2.00 & 5.77 & 1.84 & 0.12 \\
\hline \multirow{18}{*}{$\begin{array}{l}\text { Moderate Water } \\
\text { Stress }\end{array}$} & $\mathrm{H}_{1} \times{ }_{2}$ & $0.85^{\mathrm{ns}}$ & $13.92^{* *}$ & $-0.31^{\mathrm{ns}}$ & $0.17^{\mathrm{ns}}$ & $-1.22^{\mathrm{ns}}$ & $-0.15^{\mathrm{ns}}$ \\
\hline & $\mathrm{H}_{1} \times{ }_{3}$ & $0.36^{\mathrm{ns}}$ & $3.73^{\mathrm{ns}}$ & $-0.43^{\mathrm{ns}}$ & $-0.45^{\mathrm{ns}}$ & $-1.24^{*}$ & $-0.16^{\mathrm{ns}}$ \\
\hline & $\mathrm{H}_{1} \times{ }_{4}$ & $1.43^{\mathrm{ns}}$ & $4.23^{\mathrm{ns}}$ & $1.35^{*}$ & $1.57^{\mathrm{ns}}$ & $2.61^{* *}$ & $0.15^{\mathrm{ns}}$ \\
\hline & $\mathrm{H}_{1} \times{ }_{5}$ & $1.61^{\mathrm{ns}}$ & $4.12^{\mathrm{ns}}$ & $-0.65^{\mathrm{ns}}$ & $0.33^{\mathrm{ns}}$ & $-1.71^{* *}$ & $-0.22^{*}$ \\
\hline & $\mathrm{H}_{1} \times{ }_{6}$ & $3.26^{*}$ & $-4.04^{\mathrm{ns}}$ & $0.62^{\mathrm{ns}}$ & $-0.85^{\mathrm{ns}}$ & $4.81^{* *}$ & $0.70^{* *}$ \\
\hline & $\mathrm{H}_{2} \times{ }_{3}$ & $2.49^{\mathrm{ns}}$ & $-1.30^{\mathrm{ns}}$ & $-0.06^{\mathrm{ns}}$ & $-0.23^{\mathrm{ns}}$ & $-0.38^{n s}$ & $-0.06^{\mathrm{ns}}$ \\
\hline & $\mathrm{H}_{2} \times{ }_{4}$ & $0.69^{\mathrm{ns}}$ & $2.56^{\mathrm{ns}}$ & $-0.11^{\mathrm{ns}}$ & $0.78^{\mathrm{ns}}$ & $2.59^{* *}$ & $0.23^{*}$ \\
\hline & $\mathrm{H}_{2} \times 5$ & $1.67^{\mathrm{ns}}$ & $-3.51^{\mathrm{ns}}$ & $-1.40^{*}$ & $-0.59^{\mathrm{ns}}$ & $-1.34^{*}$ & $-0.17^{\mathrm{ns}}$ \\
\hline & $\mathrm{H}_{2} \times 6$ & $1.66^{\mathrm{ns}}$ & $-2.90^{\mathrm{ns}}$ & $0.63^{\mathrm{ns}}$ & $-0.04^{\mathrm{ns}}$ & $2.77^{* *}$ & $0.47^{* *}$ \\
\hline & $\mathrm{H}_{3} \times{ }_{4}$ & $3.47^{*}$ & $11.04^{* *}$ & $-0.63^{\mathrm{ns}}$ & $1.83^{*}$ & $1.06^{\mathrm{ns}}$ & $0.03^{\mathrm{ns}}$ \\
\hline & $\mathrm{H}_{3} \times{ }_{5}$ & $1.22^{\mathrm{ns}}$ & $-3.26^{\mathrm{ns}}$ & $-0.86^{\mathrm{ns}}$ & $-0.18^{\mathrm{ns}}$ & $-0.55^{\mathrm{ns}}$ & $-0.10^{\mathrm{ns}}$ \\
\hline & $\mathrm{H}_{3} \times 6$ & $1.40^{\mathrm{ns}}$ & $4.35^{\mathrm{ns}}$ & $-0.12^{\mathrm{ns}}$ & $-0.19^{\mathrm{ns}}$ & $2.69^{* *}$ & $0.51^{* *}$ \\
\hline & $\mathrm{H}_{4} \times{ }_{5}$ & $2.02^{\mathrm{ns}}$ & $0.80^{\mathrm{ns}}$ & $-0.05^{\mathrm{ns}}$ & $0.61^{\mathrm{ns}}$ & $2.20^{* *}$ & $0.18^{\mathrm{ns}}$ \\
\hline & $\mathrm{H}_{4} \times 6$ & $0.64^{\mathrm{ns}}$ & $-5.03^{\mathrm{ns}}$ & $2.89^{* *}$ & $2.52^{* *}$ & $1.70^{* *}$ & $-0.26^{* *}$ \\
\hline & $\mathrm{H}_{5} \times 6$ & $1.02^{\mathrm{ns}}$ & $4.60^{\mathrm{ns}}$ & $0.37^{\mathrm{ns}}$ & $-0.05^{\mathrm{ns}}$ & $3.67^{* *}$ & $0.66^{* *}$ \\
\hline & LSD (sij) & 3.11 & 6.30 & 1.20 & 1.70 & 0.98 & 0.19 \\
\hline & LSD (sij-sik) & 4.63 & 9.41 & 1.78 & 2.53 & 1.47 & 0.28 \\
\hline & LSD (sij-skl) & 4.29 & 8.71 & 1.65 & 2.35 & 1.36 & 0.26 \\
\hline \multirow{18}{*}{$\begin{array}{l}\text { Sever Water } \\
\text { Stress }\end{array}$} & $\mathrm{H}_{1} \times{ }_{2}$ & $-1.27^{\mathrm{ns}}$ & $-3.50^{\mathrm{ns}}$ & $0.15^{\mathrm{ns}}$ & $-0.64^{\mathrm{ns}}$ & $-0.42^{\mathrm{ns}}$ & $-0.030^{\mathrm{ns}}$ \\
\hline & $\mathrm{H}_{1} \times{ }_{3}$ & $-0.90^{\mathrm{ns}}$ & $4.98^{\mathrm{ns}}$ & $-0.22^{\mathrm{ns}}$ & $0.18^{\mathrm{ns}}$ & $-0.72^{\mathrm{ns}}$ & $-0.121^{\mathrm{ns}}$ \\
\hline & $\mathrm{H}_{1} \times{ }_{4}$ & $2.81^{*}$ & $3.55^{\mathrm{ns}}$ & $0.65^{\mathrm{ns}}$ & $0.91^{\mathrm{ns}}$ & $0.54^{\mathrm{ns}}$ & $0.004^{\mathrm{ns}}$ \\
\hline & $\mathrm{H}_{1} \times{ }_{5}$ & $0.81^{\mathrm{ns}}$ & $1.95^{\mathrm{ns}}$ & $-0.63^{\mathrm{ns}}$ & $-0.44^{\mathrm{ns}}$ & $-0.99^{\mathrm{ns}}$ & $-0.107^{n s}$ \\
\hline & $\mathrm{H}_{1} \times{ }_{6}$ & $3.49^{* * *}$ & $6.95^{\mathrm{ns}}$ & $0.05^{\mathrm{ns}}$ & $0.25^{\mathrm{ns}}$ & $2.18^{* *}$ & $0.314^{* *}$ \\
\hline & $\mathrm{H}_{2} \times{ }_{3}$ & $-0.31^{\mathrm{ns}}$ & $-1.28^{\mathrm{ns}}$ & $-0.74^{*}$ & $-0.03^{\mathrm{ns}}$ & $0.70^{\mathrm{ns}}$ & $0.105^{\mathrm{ns}}$ \\
\hline & $\mathrm{H}_{2} \times{ }_{4}$ & $-0.49^{\mathrm{ns}}$ & $-5.89^{\mathrm{ns}}$ & $0.37^{\mathrm{ns}}$ & $0.50^{\mathrm{ns}}$ & $1.28^{*}$ & $0.162^{\mathrm{ns}}$ \\
\hline & $\mathrm{H}_{2} \times 5$ & $0.01^{\mathrm{ns}}$ & $2.95^{\mathrm{ns}}$ & $-0.05^{\mathrm{ns}}$ & $-0.25^{\mathrm{ns}}$ & $-0.87^{\mathrm{ns}}$ & $-0.108^{\mathrm{ns}}$ \\
\hline & $\mathrm{H}_{2} \times{ }_{6}$ & $1.15^{\mathrm{ns}}$ & $0.31^{\mathrm{ns}}$ & $0.47^{\mathrm{ns}}$ & $0.34^{\mathrm{ns}}$ & $-0.10^{\mathrm{ns}}$ & $-0.032^{\mathrm{ns}}$ \\
\hline & $\mathrm{H}_{3} \times{ }_{4}$ & $-0.76^{\mathrm{ns}}$ & $1.36^{\mathrm{ns}}$ & $-0.27^{\mathrm{ns}}$ & $0.66^{\mathrm{ns}}$ & $0.55^{\mathrm{ns}}$ & $0.030^{\mathrm{ns}}$ \\
\hline & $\mathrm{H}_{3} \times{ }_{5}$ & $0.25^{\mathrm{ns}}$ & $-7.17 *$ & $0.21^{\mathrm{ns}}$ & $-0.46^{\mathrm{ns}}$ & $-0.33^{\mathrm{ns}}$ & $-0.015^{\mathrm{ns}}$ \\
\hline & $\mathrm{H}_{3} \times{ }_{6}$ & $2.79^{*}$ & $-0.04^{\mathrm{ns}}$ & $0.19^{\mathrm{ns}}$ & $0.26^{\mathrm{ns}}$ & $1.63^{* *}$ & $0.302^{* *}$ \\
\hline & $\mathrm{H}_{4} \times{ }_{5}$ & $-2.11^{\mathrm{ns}}$ & $-2.87^{\mathrm{ns}}$ & $-0.45^{\mathrm{ns}}$ & $0.37^{\mathrm{ns}}$ & $1.85^{* *}$ & $0.221^{*}$ \\
\hline & $\mathrm{H}_{4} \times{ }_{6}$ & $3.10^{* *}$ & $-2.74^{\mathrm{ns}}$ & $0.77^{*}$ & $-1.01^{\mathrm{ns}}$ & $1.07^{\mathrm{ns}}$ & $0.296^{* *}$ \\
\hline & $\mathrm{H}_{5} \times{ }_{6}$ & $-0.23^{\mathrm{ns}}$ & $5.00^{\mathrm{ns}}$ & $0.25^{\mathrm{ns}}$ & $1.48^{* *}$ & $1.76^{* *}$ & $0.100^{\mathrm{ns}}$ \\
\hline & LSD (sij) & 2.27 & 7.31 & 0.70 & 1.06 & 0.92 & 0.15 \\
\hline & LSD (sij-sik) & 3.38 & 10.91 & 1.04 & 1.59 & 1.38 & 0.22 \\
\hline & LSD (sij-skl) & 3.13 & 10.10 & 0.96 & 1.47 & 1.28 & 0.21 \\
\hline
\end{tabular}

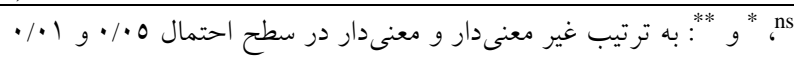

ns, * and ${ }^{* *}$ : non-significant \& significant at the $0.05 \& 0.01$ probability level, respectively 


$$
\text { جدول } 7 \text { - برآورد تركيبريذيرى خصوصى تلاقى ها در نسل F2 براى صفات در شرايط بدون تنش و تنش خشكى }
$$

Table 6. Estimation of specific combining ability of the crosses in $\mathrm{F}_{2}$ generation under non-stress and drought

\begin{tabular}{|c|c|c|c|c|c|c|c|}
\hline Water treatment & $\mathrm{F}_{2 \mathrm{~S}}$ & $\mathrm{PH}$ & $\mathrm{LN}$ & $\mathrm{BN}$ & BY & FY & $\mathrm{HI}$ \\
\hline \multirow{18}{*}{ Well Watered } & $\mathrm{H}_{1} \times{ }_{2}$ & $2.05^{\mathrm{ns}}$ & $26.57^{* *}$ & $0.24^{\mathrm{ns}}$ & $0.48^{*}$ & $-2.02^{* *}$ & $-0.11^{*}$ \\
\hline & $\mathrm{H}_{1} \times{ }_{3}$ & $-0.60^{\mathrm{ns}}$ & $-9.13^{\mathrm{ns}}$ & $-0.48^{\mathrm{ns}}$ & $4.84^{*}$ & $-0.97^{\mathrm{ns}}$ & $-0.15^{* *}$ \\
\hline & $\mathrm{H}_{1} \times{ }_{4}$ & $-1.10^{\mathrm{ns}}$ & $-13.60^{\mathrm{ns}}$ & $0.61^{\mathrm{ns}}$ & $1.44^{\mathrm{ns}}$ & $2.69^{* *}$ & $0.10^{*}$ \\
\hline & $\mathrm{H}_{1} \times{ }_{5}$ & $0.24^{\mathrm{ns}}$ & $2.04^{\mathrm{ns}}$ & $0.13^{\text {ns }}$ & $0.92^{\mathrm{ns}}$ & $-0.50^{\mathrm{ns}}$ & $-0.01^{\mathrm{ns}}$ \\
\hline & $\mathrm{H}_{1} \times 6$ & $-0.54^{\mathrm{ns}}$ & $30.41^{* *}$ & $0.17^{\mathrm{ns}}$ & $4.50^{*}$ & $3.03^{* *}$ & $-0.08^{\mathrm{ns}}$ \\
\hline & $\mathrm{H}_{2} \times 3$ & $-1.02^{\mathrm{ns}}$ & $-4.35^{\mathrm{ns}}$ & $-0.06^{\mathrm{ns}}$ & $-2.35^{\mathrm{ns}}$ & $-0.84^{\mathrm{ns}}$ & $-0.10^{*}$ \\
\hline & $\mathrm{H}_{2} \times{ }_{4}$ & $0.83^{\mathrm{ns}}$ & $9.40^{\mathrm{ns}}$ & $0.36^{\mathrm{ns}}$ & $4.57^{*}$ & $0.04^{\mathrm{ns}}$ & $-0.04^{\mathrm{ns}}$ \\
\hline & $\mathrm{H}_{2} \times 5$ & $-1.25^{\mathrm{ns}}$ & $-2.28^{\mathrm{ns}}$ & $-0.43^{\mathrm{ns}}$ & $-1.79^{\mathrm{ns}}$ & $-1.64^{*}$ & $-0.10^{*}$ \\
\hline & $\mathrm{H}_{2} \times 6$ & $-0.42^{\mathrm{ns}}$ & $-10.69^{\mathrm{ns}}$ & $-1.03^{\mathrm{ns}}$ & $-4.96^{*}$ & $2.79^{* *}$ & $0.47^{* *}$ \\
\hline & $\mathrm{H}_{3} \times{ }_{4}$ & $3.78^{* *}$ & $11.91^{\mathrm{ns}}$ & $1.77^{* *}$ & $5.80^{* *}$ & $1.65^{*}$ & $-0.06^{\mathrm{ns}}$ \\
\hline & $\mathrm{H}_{3} \times 5$ & $1.44^{\mathrm{ns}}$ & $1.71^{\mathrm{ns}}$ & $-0.56^{\mathrm{ns}}$ & $-2.98^{\mathrm{ns}}$ & $-1.18^{\mathrm{ns}}$ & $-0.07^{\mathrm{ns}}$ \\
\hline & $\mathrm{H}_{3} \times 6$ & $0.11^{\mathrm{ns}}$ & $-10.88^{\mathrm{ns}}$ & $-0.98^{\mathrm{ns}}$ & $-7.25^{* *}$ & $0.96^{\mathrm{ns}}$ & $0.65^{* *}$ \\
\hline & $\mathrm{H}_{4} \times{ }_{5}$ & $1.44^{\mathrm{ns}}$ & $19.05^{*}$ & $1.56^{* *}$ & $6.12^{* *}$ & $2.40^{* *}$ & $0.05^{\mathrm{ns}}$ \\
\hline & $\mathrm{H}_{4} \times 6$ & $-0.76^{\mathrm{ns}}$ & $47.18^{* *}$ & $0.70^{\mathrm{ns}}$ & $7.10^{* *}$ & $0.59^{\mathrm{ns}}$ & $-0.22^{* *}$ \\
\hline & $\mathrm{H}_{5} \times 6$ & $-1.28^{\mathrm{ns}}$ & $-4.87^{\mathrm{ns}}$ & $-0.94^{\mathrm{ns}}$ & $-1.78^{\mathrm{ns}}$ & $1.21^{\mathrm{ns}}$ & $0.07^{\mathrm{ns}}$ \\
\hline & LSD (sij) & 2.16 & 19.23 & 1.00 & 3.98 & 1.23 & 0.08 \\
\hline & LSD (sij-sik) & 3.23 & 28.70 & 1.49 & 5.94 & 1.84 & 0.12 \\
\hline & LSD (sij-skl) & 2.99 & 26.57 & 1.38 & 5.50 & 1.70 & 0.11 \\
\hline \multirow{18}{*}{$\begin{array}{l}\text { Moderate Water } \\
\text { Stress }\end{array}$} & $\mathrm{H}_{1} \times_{2}$ & $0.15^{\mathrm{ns}}$ & $9.28^{* * *}$ & $-0.53^{\mathrm{ns}}$ & $0.57^{\mathrm{ns}}$ & $-0.88^{\mathrm{ns}}$ & $-0.12^{\mathrm{ns}}$ \\
\hline & $\mathrm{H}_{1} \times{ }_{3}$ & $-0.19^{\mathrm{ns}}$ & $2.98^{\mathrm{ns}}$ & $-0.02^{\mathrm{ns}}$ & $-0.54^{\mathrm{ns}}$ & $-1.03^{\mathrm{ns}}$ & $-0.13^{\mathrm{ns}}$ \\
\hline & $\mathrm{H}_{1} \times{ }_{4}$ & $3.17^{* *}$ & $4.89^{\mathrm{ns}}$ & $0.70^{\mathrm{ns}}$ & $1.14^{\mathrm{ns}}$ & $2.05^{* *}$ & $0.13^{\mathrm{ns}}$ \\
\hline & $\mathrm{H}_{1} \times{ }_{5}$ & $-0.78^{n s}$ & $2.53^{\mathrm{ns}}$ & $-0.45^{\mathrm{ns}}$ & $-0.01^{\mathrm{ns}}$ & $-1.11^{\mathrm{ns}}$ & $-0.12^{\mathrm{ns}}$ \\
\hline & $\mathrm{H}_{1} \times{ }_{6}$ & $3.00^{* *}$ & $-3.21 \mathrm{~ns}$ & $0.30^{\mathrm{ns}}$ & $-0.42^{\mathrm{ns}}$ & $3.48^{* *}$ & $0.46^{* *}$ \\
\hline & $\mathrm{H}_{2} \times 3$ & $1.45^{\mathrm{ns}}$ & $1.07^{\mathrm{ns}}$ & $-1.63^{* *}$ & $-0.28^{\mathrm{ns}}$ & $-0.10^{\mathrm{ns}}$ & $-0.03^{\mathrm{ns}}$ \\
\hline & $\mathrm{H}_{2} \times{ }_{4}$ & $2.81^{* *}$ & $-1.88^{\mathrm{ns}}$ & $-0.02^{\mathrm{ns}}$ & $0.72^{\text {ns }}$ & $1.21^{\mathrm{ns}}$ & $0.11^{\mathrm{ns}}$ \\
\hline & $\mathrm{H}_{2} \times 5$ & $0.52^{\mathrm{ns}}$ & $-3.88^{n s}$ & $-0.74^{\mathrm{ns}}$ & $0.07^{\mathrm{ns}}$ & $-0.81^{\mathrm{ns}}$ & $-0.12^{\mathrm{ns}}$ \\
\hline & $\mathrm{H}_{2} \times 6$ & $1.96^{\mathrm{ns}}$ & $-0.52^{\mathrm{ns}}$ & $0.90^{\mathrm{ns}}$ & $-0.54^{\mathrm{ns}}$ & $2.18^{* *}$ & $0.43^{* * *}$ \\
\hline & $\mathrm{H}_{3} \times{ }_{4}$ & $1.79^{\mathrm{ns}}$ & $8.94^{* *}$ & $-0.41^{\mathrm{ns}}$ & $1.89^{*}$ & $0.75^{\mathrm{ns}}$ & $0.01^{\mathrm{ns}}$ \\
\hline & $\mathrm{H}_{3} \times{ }_{5}$ & $-0.18^{\mathrm{ns}}$ & $0.87^{\mathrm{ns}}$ & $-0.33^{\mathrm{ns}}$ & $-0.15^{\mathrm{ns}}$ & $-0.21^{\mathrm{ns}}$ & $-0.04^{\mathrm{ns}}$ \\
\hline & $\mathrm{H}_{3} \times{ }_{6}$ & $0.25^{\mathrm{ns}}$ & $2.51^{\mathrm{ns}}$ & $0.53^{\mathrm{ns}}$ & $-0.04^{\mathrm{ns}}$ & $1.73^{* *}$ & $0.37^{* *}$ \\
\hline & $\mathrm{H}_{4} \times{ }_{5}$ & $-0.18^{\mathrm{ns}}$ & $1.42^{\mathrm{ns}}$ & $0.45^{\mathrm{ns}}$ & $0.10^{\mathrm{ns}}$ & $1.24^{\mathrm{ns}}$ & $0.15^{\mathrm{ns}}$ \\
\hline & $\mathrm{H}_{4} \times 6$ & $0.57^{\mathrm{ns}}$ & $-2.50^{\mathrm{ns}}$ & $0.99^{*}$ & $1.97^{*}$ & $1.92^{* *}$ & $-0.14^{\mathrm{ns}}$ \\
\hline & $\mathrm{H}_{5} \times 6$ & $1.13^{\mathrm{ns}}$ & $2.65^{\mathrm{ns}}$ & $0.36^{\mathrm{ns}}$ & $0.44^{\mathrm{ns}}$ & $1.48^{*}$ & $0.20^{\mathrm{ns}}$ \\
\hline & LSD (sij) & 2.24 & 5.52 & 0.98 & 1.66 & 1.10 & 0.21 \\
\hline & LSD (sij-sik) & 3.35 & 8.23 & 1.46 & 2.47 & 1.65 & 0.31 \\
\hline & LSD (sij-skl) & 3.10 & 7.62 & 1.35 & 2.29 & 1.52 & 0.29 \\
\hline \multirow{18}{*}{ Sever Water Stress } & $\mathrm{H}_{1} \times 2$ & $-0.04^{\mathrm{ns}}$ & $-3.13^{\mathrm{ns}}$ & $-0.31^{\mathrm{ns}}$ & $-0.42^{\mathrm{ns}}$ & $-0.51^{\mathrm{ns}}$ & $-0.057^{\mathrm{ns}}$ \\
\hline & $\mathrm{H}_{1} \times{ }_{3}$ & $-0.85^{\mathrm{ns}}$ & $2.67^{\mathrm{ns}}$ & $-0.12^{\mathrm{ns}}$ & $0.03^{\mathrm{ns}}$ & $-0.53^{\mathrm{ns}}$ & $-0.080^{\mathrm{ns}}$ \\
\hline & $\mathrm{H}_{1} \times{ }_{4}$ & $0.78^{\mathrm{ns}}$ & $2.73^{\mathrm{ns}}$ & $0.54^{*}$ & $0.47^{\mathrm{ns}}$ & $0.20^{\mathrm{ns}}$ & $0.002^{\mathrm{ns}}$ \\
\hline & $\mathrm{H}_{1} \times{ }_{5}$ & $-0.92^{\mathrm{ns}}$ & $1.47^{\mathrm{ns}}$ & $-0.28^{\mathrm{ns}}$ & $-0.31^{\mathrm{ns}}$ & $-0.71^{\mathrm{ns}}$ & $-0.056^{\mathrm{ns}}$ \\
\hline & $\mathrm{H}_{1} \times 6$ & $3.43^{* *}$ & $5.61^{\mathrm{ns}}$ & $0.26^{\mathrm{ns}}$ & $0.63^{\mathrm{ns}}$ & $1.41^{*}$ & $0.104^{\mathrm{ns}}$ \\
\hline & $\mathrm{H}_{2} \times 3$ & $-1.30^{\mathrm{ns}}$ & $2.10^{\mathrm{ns}}$ & $0.18^{\mathrm{ns}}$ & $-0.04^{\mathrm{ns}}$ & $0.55^{\mathrm{ns}}$ & $0.082^{\mathrm{ns}}$ \\
\hline & $\mathrm{H}_{2} \times{ }_{4}$ & $-1.57^{\mathrm{ns}}$ & $-3.31^{\mathrm{ns}}$ & $-0.14^{\mathrm{ns}}$ & $0.28^{\mathrm{ns}}$ & $1.50^{*}$ & $0.208^{\mathrm{ns}}$ \\
\hline & $\mathrm{H}_{2} \times{ }_{5}$ & $0.25^{\mathrm{ns}}$ & $2.59^{\mathrm{ns}}$ & $-0.27^{\mathrm{ns}}$ & $-0.18^{\mathrm{ns}}$ & $-0.82^{\mathrm{ns}}$ & $-0.111^{\mathrm{ns}}$ \\
\hline & $\mathrm{H}_{2} \times 6$ & $1.42^{\mathrm{ns}}$ & $0.99^{\mathrm{ns}}$ & $0.41^{\mathrm{ns}}$ & $0.46^{\mathrm{ns}}$ & $0.16^{\mathrm{ns}}$ & $0.030^{\mathrm{ns}}$ \\
\hline & $\mathrm{H}_{3} \times{ }_{4}$ & $-1.18^{\mathrm{ns}}$ & $0.10^{\mathrm{ns}}$ & $-0.09^{\mathrm{ns}}$ & $0.83^{\mathrm{ns}}$ & $0.44^{\mathrm{ns}}$ & $-0.012^{\mathrm{ns}}$ \\
\hline & $\mathrm{H}_{3} \times{ }_{5}$ & $-2.34^{*}$ & $0.26^{\mathrm{ns}}$ & $-0.10^{\mathrm{ns}}$ & $-0.40^{\mathrm{ns}}$ & $-0.14^{\mathrm{ns}}$ & $-0.004^{\mathrm{ns}}$ \\
\hline & $\mathrm{H}_{3} \times{ }_{6}$ & $0.94^{\mathrm{ns}}$ & $0.34^{\mathrm{ns}}$ & $-0.02^{\mathrm{ns}}$ & $0.07^{\mathrm{ns}}$ & $1.26^{*}$ & $0.290^{* *}$ \\
\hline & $\mathrm{H}_{4} \times{ }_{5}$ & $-0.59^{\mathrm{ns}}$ & $-1.90^{\mathrm{ns}}$ & $0.25^{\mathrm{ns}}$ & $0.60^{\mathrm{ns}}$ & $1.20^{*}$ & $0.125^{\mathrm{ns}}$ \\
\hline & $\mathrm{H}_{4} \times 6$ & $2.26^{*}$ & $3.10^{\mathrm{ns}}$ & $0.53^{*}$ & $-1.08^{*}$ & $0.91^{\mathrm{ns}}$ & $0.269^{*}$ \\
\hline & $\mathrm{H}_{5} \times 6$ & $1.03^{\mathrm{ns}}$ & $2.72^{\mathrm{ns}}$ & $0.15^{\mathrm{ns}}$ & $1.25^{* *}$ & $1.42^{*}$ & $0.071^{\mathrm{ns}}$ \\
\hline & LSD (sij) & 2.02 & 6.01 & 0.51 & 0.94 & 0.90 & 0.17 \\
\hline & LSD (sij-sik) & 3.02 & 8.97 & 0.76 & 1.40 & 1.34 & 0.26 \\
\hline & LSD (sij-skl) & 2.79 & 8.31 & 0.71 & 1.30 & 1.24 & 0.24 \\
\hline
\end{tabular}

ns ${ }^{*}$ and ${ }^{* *}$ : non-significant \& significant at the $0.05 \& 0.01$ probability level, respectively 


$$
\begin{aligned}
& \text { و الدهاى انتخاب شده، والد P4 در آبيارى معمولى و تنش } \\
& \text { خشكى ملايم و والد P6 در تنش خشكى شديد بهترين } \\
& \text { والدها براى استفاده به عنوان والد دهنده در توسعه } \\
& \text { واريتههاى گشنيز با عملكرد بالا در شرايط آبيارى مطالعه } \\
& \text { شده بودند. همجنين نتايج برآورد بارامترهاى زنتيكى نشان } \\
& \text { داد كه اثرات افزايشى در كنترل صفات ارتفاع بوته، تعداد } \\
& \text { برگ، تعداد شاخه و عملكرد بيولوزيك مهمتر بودند. } \\
& \text { اهميت بيشتر اثرات افزايشى بيانخر كارايى بالاى انتخاب } \\
& \text { در نسلهاى اول حاصل از تلاقى در اصلاح اين صفات } \\
& \text { بود. در حالى كه نقش اثرات غيرافزايشى زنى در كنترل } \\
& \text { صفات شاخص برداشت و عملكرد ميوه بيشتر از اثرات } \\
& \text { افزايشى بود. بنابراين تهيه دورگهاى برتر با استفاده از } \\
& \text { روشهاى بهنزادى مبتنى بر آزمون نتاج جهت بهبود اين } \\
& \text { صفات موثر خواهد بود }
\end{aligned}
$$

$$
\begin{aligned}
& \text { در اين مطالعه نقش اثرات غيرافزايشى زنى در كنترل } \\
& \text { صفات شاخص برداشت و عملكرد ميوه بيشتر از اثرات } \\
& \text { افزايشى بود. در نتيجه كزينش و بيشرفت زنتيكى براى } \\
& \text { اين صفات محدودتر از ساير صفات مورد مطالعه مىباشد. } \\
& \text { بنابراين براى صفات عملكرد ميوه و شاخص برداشت } \\
& \text { كزينش تأخيرى در نسل هاى بيشرفته تلاقىهاى برتر اين } \\
& \text { صفات مناسب مىباشد. در زيزوهشهاى ديخر با مطالعه } \\
& \text { اجزا زنتيكى به روش دى آلل در شرايط تنش خشكى، } \\
& \text { نقش آثار غالبيت براى عملكرد ميوه گزارش شد و در اين }
\end{aligned}
$$

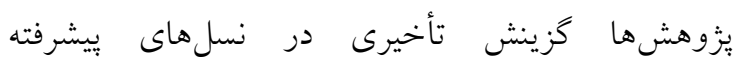

$$
\begin{aligned}
& \text { تلاقى هاى برتر براى افزايش عملكرد ميوه كشنيز بيشنهاد } \\
& \text { داده شد كه با نتايج حاضر مطالعه مطابقت داشت }
\end{aligned}
$$

.(Khodadadi et al., 2016b; Khodadadi et al., 2017) به طور كلى نتايج اين تحقيق نشان داد كه در ميان

\section{References}

Ahmadian, A., Ghanbari, A., Siahsar, B., Haydari, M., Ramroodi, M. and Mousavinik, S.M. (2011). Study of chamomiles yield and its components under drought stress and organic and inorganic fertilizers usage and their residue. Journal of Microbiology and Antimicrobials, 3: 23-28.

Ashraf, M. and Foolad, M. (2007). Roles of glycine betaine and proline in improving plant abiotic stress resistance. Environmental and Experimental Botany, 59: 206-216.

Baker, R. (1978). Issues in diallel analysis. Crop Science, 18: 533-536.

Banerjee, P. and Kole, P. (2009). Analysis of genetic architecture for some physiological characters in sesame (Sesamum indicum L.). Euphytica, 168: 11-22.

Blank, A.F., Santa Rosa, Y.R., de Carvalho Filho, J.L.S., dos Santos, C.A., de Fátima ArrigoniBlank, M., dos Santos Niculau, E. and Alves, P.B. (2012). A diallel study of yield components and essential oil constituents in basil (Ocimum basilicum L.). Industrial Crops and Products, 38: 93-98.

Blum, A. (2011). Plant Breeding for Water-Limited Environments. Springer Verlag, New York, USA.

Burt, S. (2004). Essential oils: their antibacterial properties and potential applications in foods-a review. International Journal of Food Microbiology, 94: 223-253.

Cantore, P.L., Iacobellis, N.S., De Marco, A., Capasso, F. and Senatore, F. (2004). Antibacterial activity of Cori\&rum sativum L. \& Foeniculum vulgare Miller var. vulgare (Miller) essential oils. Journal of Agricultural and Food Chemistry, 52: 7862-7866.

Chithra, V. and Leelamma, S. (2000). Coriandrum sativum-effect on lipid metabolism in 1, 2dimethyl hydrazine induced colon cancer. Journal of Ethnopharmacology, 71: 457-463.

Donald, C. and Hamblin, J. (1976). The biological yield and harvest index of cereals as agronomic and plant breeding criteria. Advances in Agronomy, 28: 361-405. 


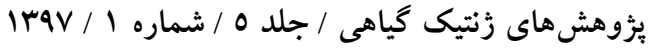

Fakerbaher, Z., Rezaei, M.B., Mehdi, M. and Abaszadeh, B. (2002). Study of quantitative and qualitative changes of essential oil (Satureja hortensis L.) during drought on the field. Iranian Journal of Medicinal and Aromatic Plants, 11: 37-51 (In Persian).

Falconer, D.S. and Mackay, T.F.C. (1996). Introduction to Quantitative Genetics. Longman, London, UK.

Gallagher, A., Flatt, P., Duffy, G. and Abdel-Wahab, Y. (2003). The effects of traditional antidiabetic plants on in vitro glucose diffusion. Nutrition Research, 23: 413-424.

Golparvar, A.R., Ghanadha, M.R., Zali, A.A. and Ahmadi, A. (2002). Evaluation of morphological traits as selection criteria in breeding of wheat. Iranian Journal of Crop Sciences 4: 202-205 (In Persian).

Griffing, B. (1956). A generalized treatment of the use of diallel crosses in quantitative inheritance. Heredity, 10: 31-50.

Hassani, A. and Omidbaigi, R. (2002). Effect of water stress on some morphological, physiological and metabolic characteristics of basil. Agricultural Science, 12(3): 47-99 (In Persian).

Joshi, S., Sharma, S., Singhania, D. and Sain, R. (2004). Combining ability in the $F_{1}$ and $F_{2}$ generations of diallel cross in hexaploid wheat (Triticum aestivum L. em. Thell). Hereditas, 141: 115-121.

Kalb, T.J. and Davis, D.W. (1984). Evaluation of combining ability, heterosis, and genetic variance for yield, maturity, and plant characteristics in bush muskmelon. Journal of the American Society for Horticultural Science, 109(3): 416-419.

Khan, N.U., Hassan, G., Kumbhar, M.B., Marwat, K.B., Khan, M.A., Parveen, A. and Saeed, M. (2009). Combining ability analysis to identify suitable parents for heterosis in seed cotton yield, its components and lint\% in upland cotton. Industrial Crops and Products, 29: 108-115.

Khodadadi, M., Dehghani, H. and Jalali-Javaran, M. (2017). Quantitative genetic analysis reveals potential to genetically improve fruit yield and drought resistance simultaneously in coriander. Frontiers in Plant Science, 8: 568.

Khodadadi, M., Dehghani, H., Jalali-Javaran, M., Rashidi-Monfared, S. and Christopher, J.T. (2016a). Numerical and graphical assessment of relationships between traits of the Iranian Coriandrum sativum L. core collection by considering genotype $\times$ irrigation interaction. Scientia Horticulturae, 200: 73-82.

Khodadadi, M., Dehghani, H., Javaran, M.J. and Christopher, J.T. (2016b). Fruit yield, fatty and essential oils content genetics in coriander. Industrial Crops and Products, 94: 72-81.

Kolmogorov, A. (1933) Sulla determinazione empirica di una legge di distribuzione. Istituto Italiano degli Attuari, 4: 83-91.

Kubo, I., Fujita, K.i., Kubo, A., Nihei, K.i. and Ogura, T. (2004). Antibacterial activity of coriander volatile compounds against Salmonella choleraesuis. Journal of Agricultural and Food Chemistry, 52: 3329-3332.

Larcher, W. (1995). Physiological Plant Ecology. Springer-Verlag Berlin Heidelberg, Berlin, DE.

Mandal, K., Saravanan, R. and Maiti, S. (2008). Effect of different levels of N, P and K on downy mildew (Peronospora plantaginis) and seed yield of isabgol (Plantago ovata). Crop Protection, 27: 988-995.

Mohammadi, M. and Roustaie, M. (2016). Estimation of Genetic Parameters of Grain Yield and Some Agronomic Traits in Bread Wheat Using Diallel Crosses. Journal of Plant Genetic Researches, 2(2): 57-72 (In Persian). 
Noroozi-Shahri, F., Pouryousef, M., Tavakoli, A., Saba, J. and Yazdinejad, A. (2015). Evaluation the performance of some of Iran's native fennel (Foeniculum vulgare Mill.) accessions under drought stress condition. Iranian Journal of Field Crop Science, 46: 49-56 (In Persian).

Razmjoo, K., Heydarizadeh, P. and Sabzalian, M.R. (2008). Effect of salinity and drought stresses on growth parameters and essential oil content of Matricaria chamomile. International Journal of Agriculture and Biology, 10: 451-454.

Reddy, A.R., Chaitanya, K.V. and Vivekanadan, M.V. (2004). Drught-induced responses of photosynthesis and Antioxidant metabolism in higher plants. Journal of Plant Physiology, 161: 1189-1202.

Sadeghzadeh-Ahari, D., Sharifi, P., Karimizadeh, R. and Mohammadi, M. (2015). Estimation of Genetic Parameters of Morphological Traits in Rainfed Durum Wheat (Triticum turgidum L.) using Diallel Method. Journal of Plant Genetic Researches, 2(1): 45-62 (In Persian).

Safikhani, F. (2006). Investigation of Physiological Aspects of Drought Resistance in Dragonhead (Dracocephaalum moldavica L.). Ph.D. thesis, Shahid Chamran University, Ahvaz, Ramin Higher Education Agriculture and Natural Resources, Ahvaz, IR (In Persian).

Sayar, R., Khemira, H. and Kharrat, M. (2007). Inheritance of deeper root length and grain yield in half-diallel durum wheat (Triticum durum) crosses. Annals of Applied Biology, 151: 213-220.

Smirnov, N. (1948). Table for estimating the goodness of fit of empirical distributions. The Annals of Mathematical Statistics, 19: 279-281.

SPSS Inc (2010). SPSS 20. Users Guied. Prentice Hall, New Jersey, USA.

Sreevalli, Y., Baskaran, K., Chandrashekara, R. and Kulkarni, R. (2000). Preliminary observations on the effect of irrigation frequency and genotypes on yield and alkaloid concentration in periwinkle. Journal of Applied Research on Medicinal and Aromatic Plants, 22: 356-358.

Tawfik, K. (2008). Effect of water stress in addition to potassiomag application on mungbean. Australian Journal of Basic and Applied Sciences, 2: 42-52.

Topal, A., Aydın, C., Akgün, N. and Babaoglu, M. (2004). Diallel cross analysis in durum wheat (Triticum durum Desf.): identification of best parents for some kernel physical features. Field Crops Research, 87: 1-12.

Townsend, T., Segura, V., Chigeza, G., Penfield, T., Rae, A., Harvey, D., Bowles, D. and Graham, I.A. (2013). The use of combining ability analysis to identify elite parents for Artemisia annua $\mathrm{F}_{1}$ hybrid production. PLOS One, 8: e61989.

Valizadeh, N., Arslan, N. and Khawar, K.M. (2017). Heterosis and heterobeltiosis studies on yield and yield components of some Turkish poppy hybrids (Papaver somniferum L.). Journal of Applied Research on Medicinal and Aromatic Plants. 109: 1-11.

Volatil, O. (2000). Coriander (Coriandrum sativum L.). Plant Foods for Human Nutrition, 51: 167172.

Wangensteen, H., Samuelsen, A.B. and Malterud, K.E. (2004). Antioxidant activity in extracts from coriander. Food Chemistry, 88: 293-297.

Zehtab-Salmasi, S., Ghasemi-Golezani, K. and Moghbeli, S. (2006). Effect of sowing date and limited irrigation on the seed yield and quality of dill (Anethum graveolens L.). Turkish Journal of Agriculture and Forestry, 30: 1-6.

Zhang, K. and John, P.C.L. (2005). Raised level of cyclin dependent kinase A after prolonged suspension culture of Nicotiana plumbaginifolia is associated with more rapid growth and division, diminished cytoskeleton and lost capacity for regeneration: implications for instability of cultured plant cells. Plant Cell Tissue and Organ Culture, 82: 295-308. 


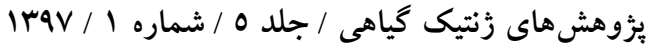

Zhang, Y., Kang, M.S. and Lamkey, K.R. (2005). Diallel-SAS05: a comprehensive program for griffing's and gardner-eberhart analyses. Agronomy Journal, 97(4): 1097-1106. 


\title{
Estimation of Genetic Parameters, General and Specific Combining Ability in Iranian Endemic Coriander Populations
}

\section{Amir Gholizadeh ${ }^{1}$, Hamid Dehghani ${ }^{2}$,*and Mostafa Khodadadi ${ }^{3}$}

1- Ph.D. Student, Department of Plant Breeding, Faculty of Agricultural, Tarbiat Modares University, Tehran, Iran

2- Associate Professor, Department of Plant Breeding, Faculty of Agricultural, Tarbiat Modares University, Tehran, Iran

3- Former Ph.D. Student, Department of Plant Breeding, Faculty of Agricultural, Tarbiat Modares University, Tehran, Iran

(Received: May 10, 2017 - Accepted: August 2, 2017)

\begin{abstract}
In any breeding program, knowledge of the nature of gene action involved in the inheritance of traits is a basic requirement. In this research, diallel crosses progenies of six coriander landrace were evaluated in $F_{1}$ and $F_{2}$ generations. The genotypes were evaluated in different irrigation conditions in three separate experiments, in which each experiment was conducted in a randomized complete block design with three replications during the growing season of 2016. Results of genetic variance analyses revealed significant mean squares of general and specific combining ability for all traits, indicating the importance of additive and non-additive genetic effects for these traits. Additive gene actions played a more important role in controlling of plant height, leaf number, branch number and biological yield, whereas the role of non-additive gene actions was more conspicuous than those of additive gene actions in controlling of harvest index and fruit yield. Therefore, providing superior hybrids using breeding methods based on progeny test will be effective to improve these traits. Also, among selected parents, $\mathrm{P}_{4}$ parent in normal irrigation and moderate water stress and $\mathrm{P}_{6}$ parent in sever water stress were the best parents for crosses in the development of high-yield varieties in coriander.
\end{abstract}

Keywords: Gen Action, Specific Combining Ability, General Combining Ability, Diallel, Coriander

\footnotetext{
*Corresponding Author, E-mail: dehghanr@modares.ac.ir
} 